QA: QA

TDR-SFR-FP-000001 REV 01

July 2001

\title{
Repository Subsurface Preliminary Fire Hazard Analysis
}

By

Richard C. Logan

Prepared for:

U.S. Department of Energy

Yucca Mountain Site Characterization Office

P.O. Box 30307

North Las Vegas, Nevada 89036-0307

Prepared by:

Bechtel SAIC Company, LLC

1180 Town Center Drive

Las Vegas, Nevada 89144

Under Contract Number

DE-AC08-01RW12101 
This report was prepared as an account of work sponsored by an agency of the United States Government. Neither the United States Government nor any agency thereof, nor any of their employees, nor any of their contractors, subcontractors or their employees, makes any warranty express or implied, or assumes any legal liability or responsibility for the accuracy, completeness, or any third party's use or the results of such use of any information, apparatus, product, or process disclosed, or represents that its use would not infringe privately owned rights. Reference herein to any specific commercial product, process, or service by trade name, trademark, manufacturer, or otherwise, does not necessarily constitute or imply its endorsement, recommendation, or favoring by the United States Government or any agency thereof or its contractors or subcontractors. The views and opinions of authors expressed herein do not necessarily state or reflect those of the United States Government or any agency thereof. 


\section{Repository Subsurface Preliminary Fire Hazard Analysis}

Prepared by:


Checked by:

John K. Kubuek John L. Kubicek

$\frac{07-30-01}{\text { Date }}$

Subsurface Design - Technical Processes

Approved by:

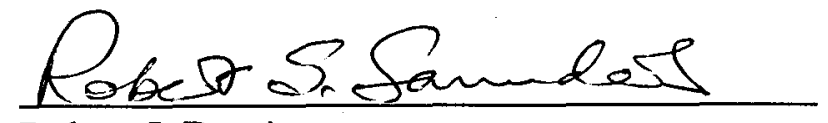

Robert J. Boutin

Subsurface Design Project Manager
$7-30-01$

Date 
INTENTIONALLY LEFT BLANK 


\section{REVISION RECORD}

\section{Revision/Change No. Description of Revision/Change}

$01 \mathrm{C}$

Total revision to update the technical report to support Site Recommendation. This revision supersedes revision 00 of the technical report which was prepared using the Enhanced Design Alternative II design requirements and referenced many of the documents prepared for the Viability Assessment design. The basis for the revision is the Lower-Temperature Operating Mode Site Recommendation design.

The revision includes a change of title from "Subsurface Fire Hazards Technical Report" to "Repository Subsurface Preliminary Fire Hazard Analysis." 
INTENTIONALLY LEFT BLANK 


\section{CONTENTS}

Page

ACRONYMS AND ABBREVIATIONS $\mathrm{XV}$

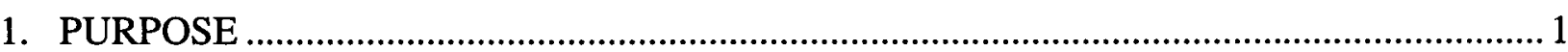

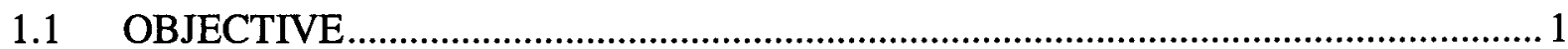

1.2 SCOPE

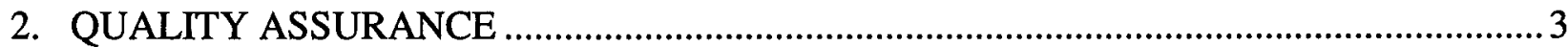

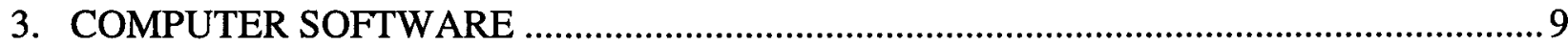

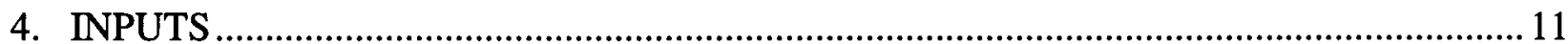



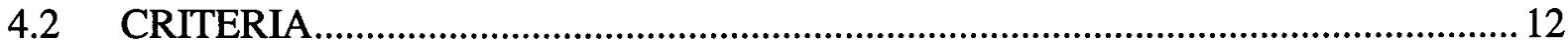

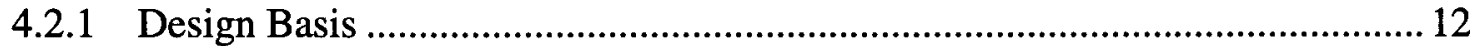

4.2.1.1 Fire Protection Functions............................................................... 12

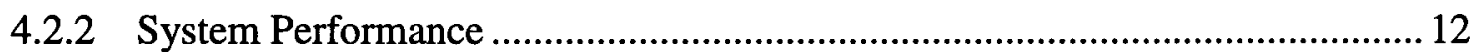

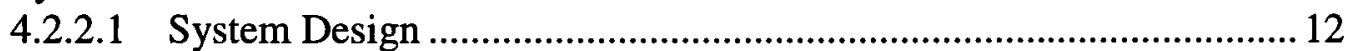

4.2.2.2 Automatic Fire Extinguishing.......................................................... 13

4.2.2.3 Redundant Fire Protection ................................................................ 13

4.2.2.4 Non-Monitored Geologic Repository Fire Response .......................... 13

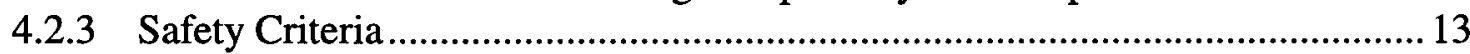

4.2.3.1 Primary and Backup Fire Protection..................................................... 13

4.2.3.2 Component Failure ..................................................................... 13

4.2.3.3 Effects of Credible Fires and Explosions .......................................... 13

4.2.3.4 Fire Protection Actuation or Failure ................................................ 13

4.2.3.5 Fire Alarms ......................................................................................... 14

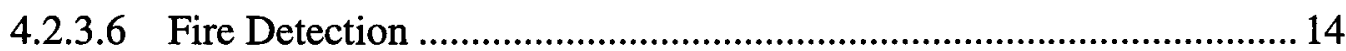

4.2.3.7 Smoke Removal/Containment ....................................................... 14

4.2.3.8 System Approval and Listing ....................................................... 14

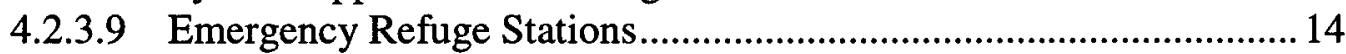

4.2.3.10 Egress Travel Time ..................................................................... 14

4.2.4 Electrical Distribution Safety Criteria ………................................................ 14

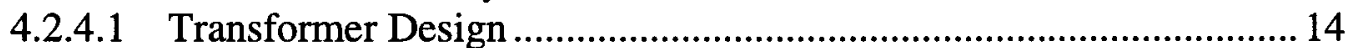

4.2.4.2 Materials ........................................................................................ 15

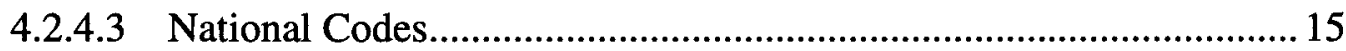

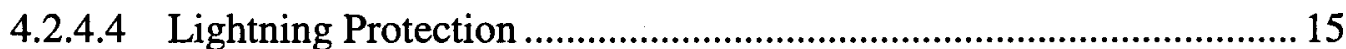

4.2.5 Guidance from U.S. Nuclear Regulatory Commission Regulatory Guidance

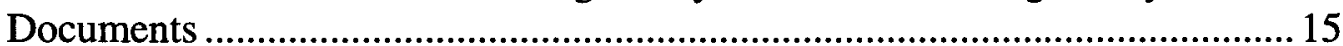

4.2.5.1 Facility Fire Brigade ..................................................................... 15

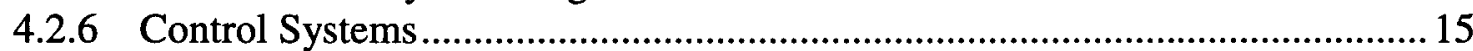

4.2.6.1 Safety and Monitoring Systems..................................................... 15

4.2.7 Ventilation System............................................................................... 16 


\section{CONTENTS (Continued)}

Page

4.2.7.1 Fresh Air Supply .......................................................................... 16

4.2.7.2 Ventilation Separation .................................................................. 16

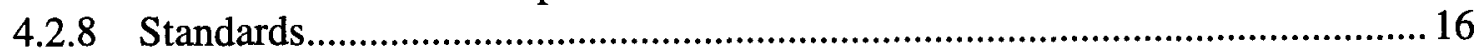

4.2.8.1 Occupational Safety and Health Standards..........................................16

4.2.8.2 Safety and Health Regulations for Construction .................................. 16

4.2.8.3 U.S. Department of Energy Orders....................................................... 16

4.2.8.4 U.S. Department of Energy Implementation Guidance......................... 16

4.2.8.5 Sprinkler Systems ................................................................................ 17

4.2.8.6 Fire Alarm Systems .......................................................................... 17

4.2.8.7 Fire Mains .................................................................................... 17

4.2.8.8 Standpipe and Hose Systems ............................................................... 17

4.2.8.9 Portable Fire Extinguishers................................................................ 17

4.2.8.10 Facilities Handling Radioactive Materials.............................................17

4.3 CODES AND STANDARDS …………….....................................................18

4.3.1 Code of Federal Regulations ......................................................................... 18

4.3.1.1 Energy...................................................................................... 18

4.3.1.2 Occupational Safety \& Health Standards ............................................ 18

4.3.1.3 Safety and Health Regulations for Construction .................................. 18

4.3.1.4 Safety and Health Standards--Underground Metal and Nonmetal

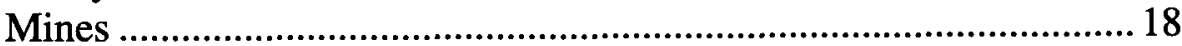

4.3.2 U.S. Department of Energy Orders............................................................... 18

4.3.2.1 Facility Safety ............................................................................... 18

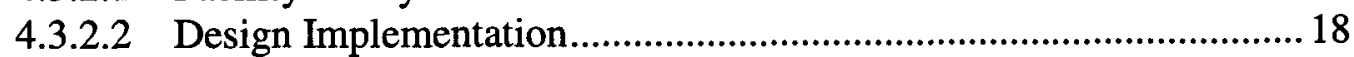

4.3.3 National Fire Protection Association............................................................. 18

4.3.3.1 Portable Fire Extinguishers................................................................ 18

4.3.3.2 Sprinkler Systems ........................................................................... 19

4.3.3.3 Standpipe and Hose Systems .............................................................. 19

4.3.3.4 Dry Chemicals .................................................................................. 19

4.3.3.5 Fire Mains ......................................................................................... 19

4.3.3.6 Flammable and Combustible Liquids ................................................. 19

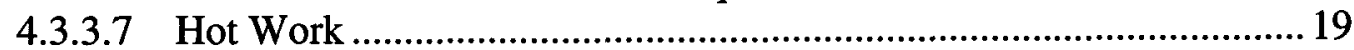

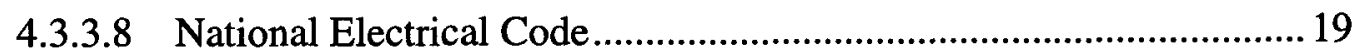

4.3.3.9 National Fire Alarm Code .............................................................. 19

4.3.3.10 Underground Mines ........................................................................ 19

4.3.3.11 Tank Vehicle Design .................................................................. 19

4.3.3.12 Lightning Protection ........................................................................20

4.3.3.13 Facilities Handling Radioactive Materials........................................20

4.3.3.14 Clean Agent Fire Extinguishing Systems .........................................20

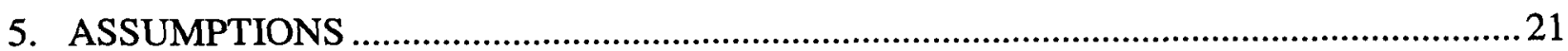

5.1 EXPLORATORY STUDIES FACILITY FIRE HAZARD ANALYSIS .....................21

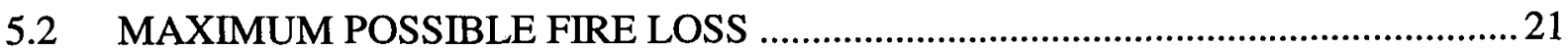




\section{CONTENTS (Continued)}

Page

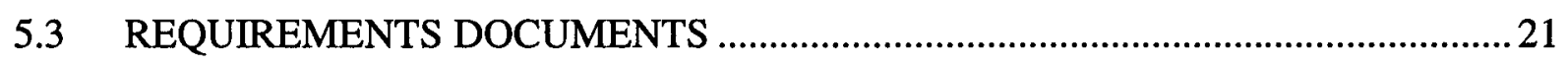

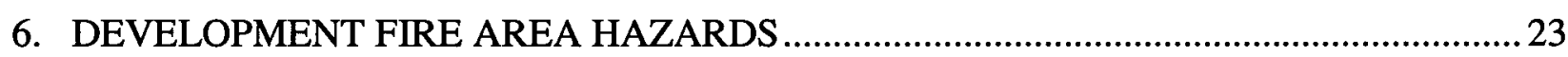

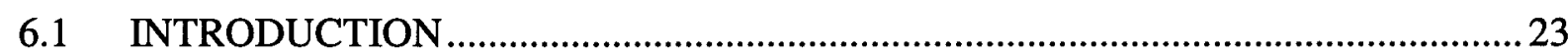

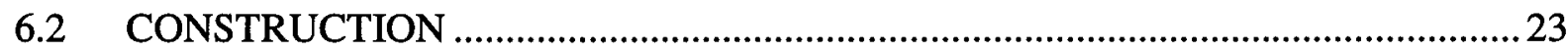

6.2.1 Major Design Elements ……………………................................................23

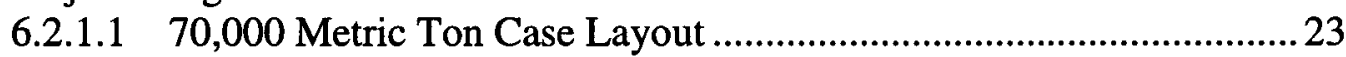

6.2.1.2 97,000 Metric Ton Case Layout ....................................................24

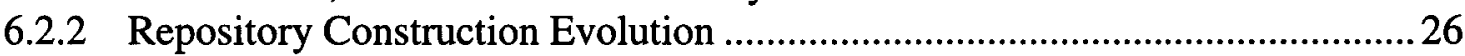

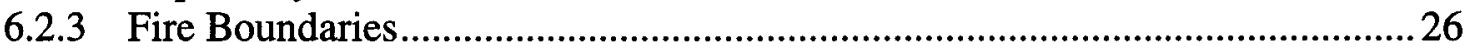

6.2.4 Ventilation System Concept .....................................................................2 27

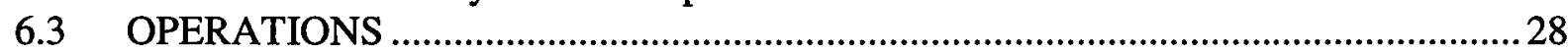

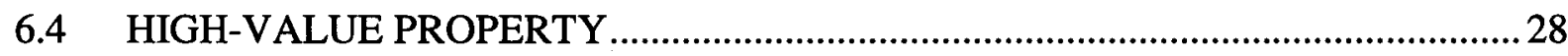

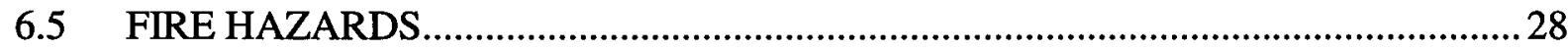

6.5.1 Tunnel Boring Machines, Railcars, and Mobile Equipment ……………….......29

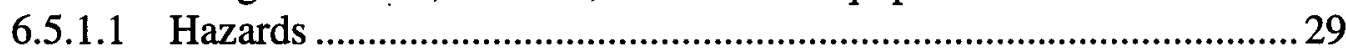

6.5.1.2 Mitigation ......................................................................................... 30

6.5.2 Fixed Electrical Equipment ............................................................................. 30

6.5.2.1 Hazards ………............................................................................ 30

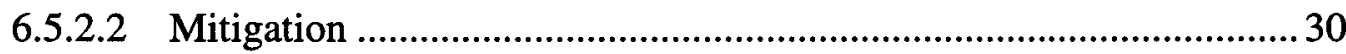

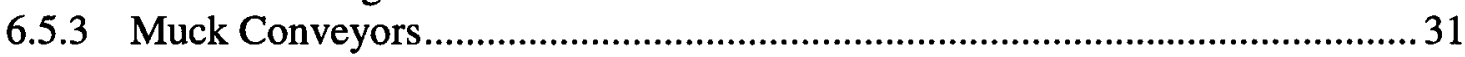

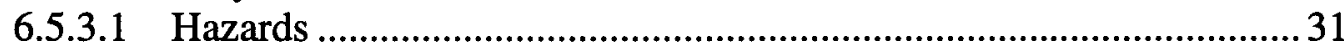

6.5.3.2 Mitigation .......................................................................................... 31

6.5.4 Operations and Monitoring Systems ……….................................................. 31

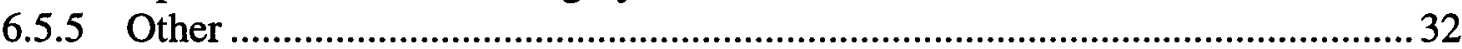

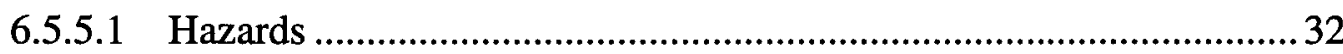

6.5.5.2 Mitigation .............................................................................. 32

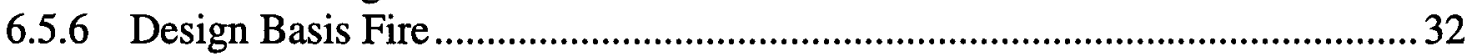

6.5.6.1 Design Basis Fire Maximum Possible Fire Loss Estimate ................. 33

6.5.6.2 Design Basis Fire Mitigation .............................................................. 33

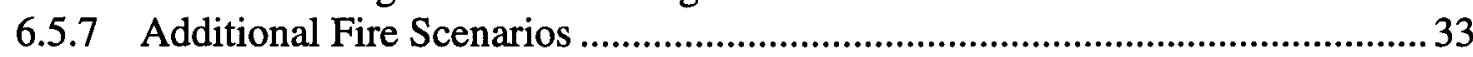

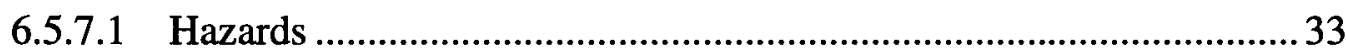

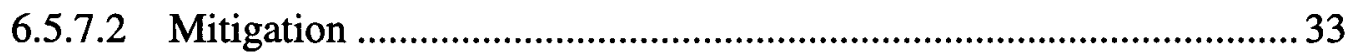

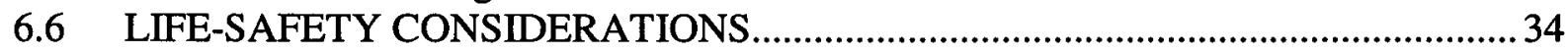

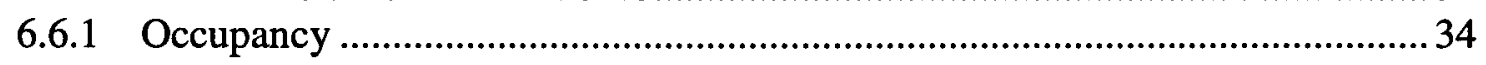

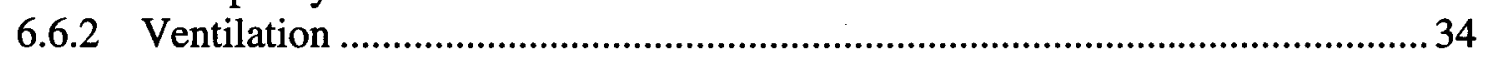

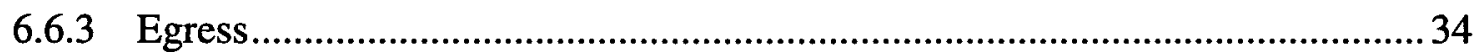

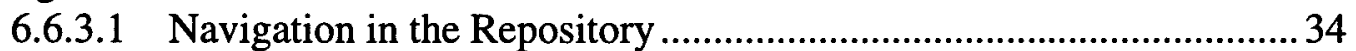

6.6.3.2 Development Phase Construction Egress .......................................... 35

6.6.3.3 Emplacement Panel Construction Egress ............................................ 35

6.6.3.4 Emplacement, Observation and Post-Closure Test Drifts ................... 35

6.6.4 Personal Respiratory Protection ..................................................................... 36 


\section{CONTENTS (Continued)}

Page

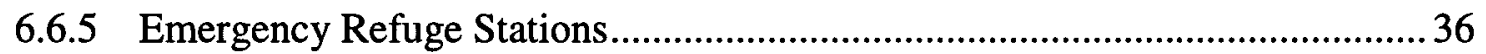

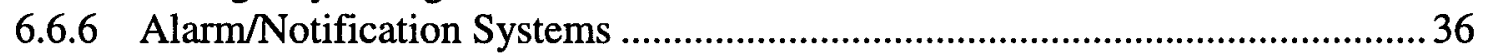

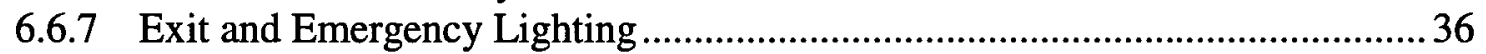

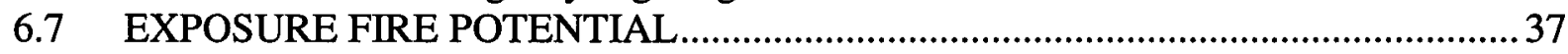

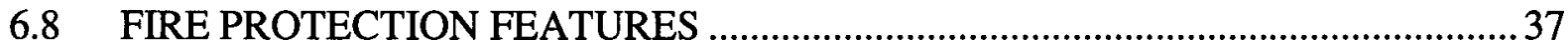

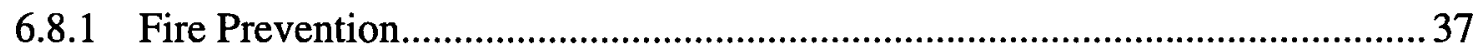

6.8.1.1 Limiting Fuel Sources.............................................................................38

6.8.1.2 Limiting Ignition Sources ............................................................. 38

6.8.1.3 Limiting Fuel and Ignition Source Contact .......................................38

6.8.2 Explosion Prevention.................................................................................... 38

6.8.3 Fire Protection ........................................................................................... 39

6.8.3.1 Choice of Extinguishing Agents ...........................................................39

6.8.3.2 Dry Chemical Agents ....................................................................... 39

6.8.3.3 Clean-Agents ................................................................................... 39

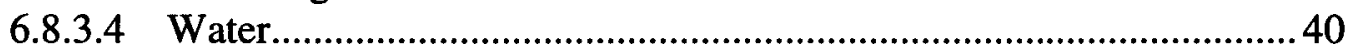

6.8.3.5 Recommended Extinguishing Agents............................................... 40

6.8.3.6 Pre-engineered Extinguishing Systems ..............................................40

6.8.3.7 Detection and Alarm Systems ………………….............................. 40

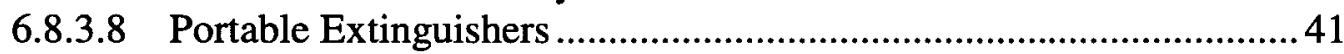

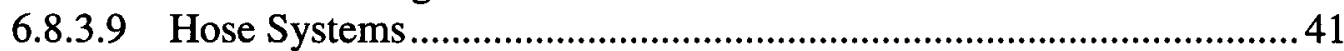

6.9 POTENTIAL FOR A HAZARDOUS INCIDENT …….............................................. 41

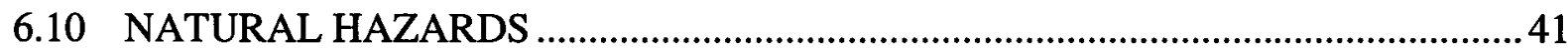

6.10.1 Potential Hazards Impacting Fire Safety .................................................... 42

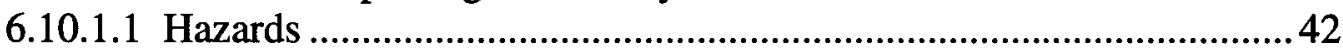

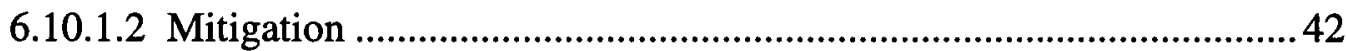

6.10.2 Potential Hazards with No Impact on Fire Safety ...........................................42

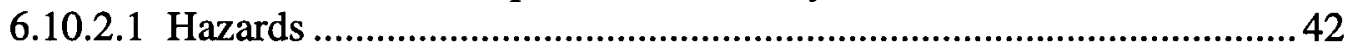

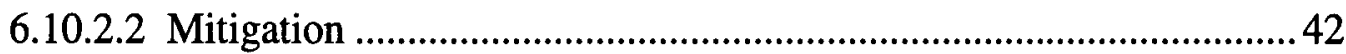

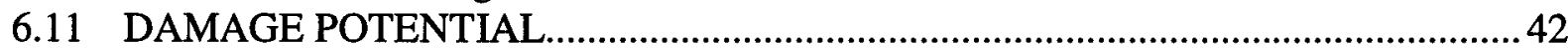

6.11.1 Unacceptable Program Interruptions ................................................................43

6.11.2 Fire Loss Potential ......................................................................................... 43

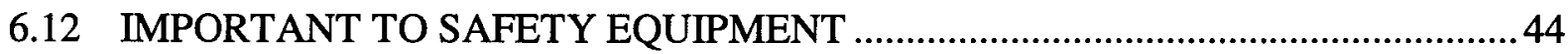



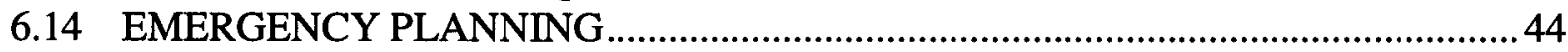

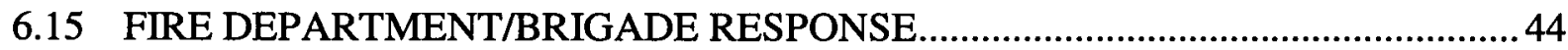

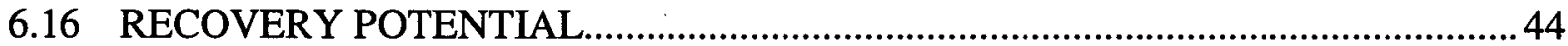

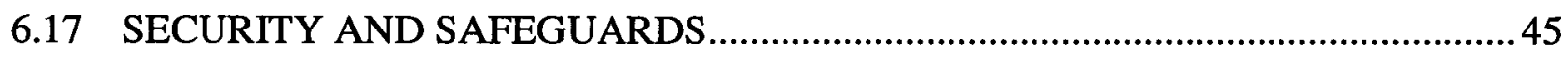

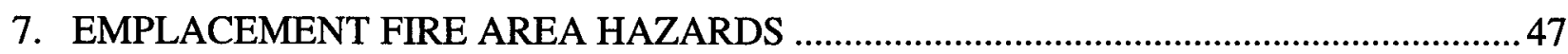

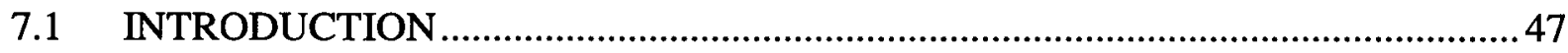

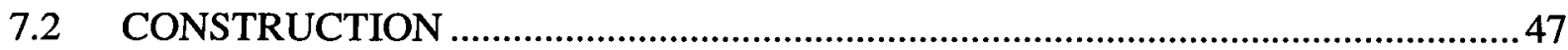

7.2.1 Design Elements ......................................................................................... 47 


\section{CONTENTS (Continued)}

Page



7.2.3 Ventilation System Concept .............................................................................4

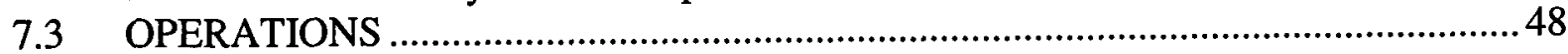

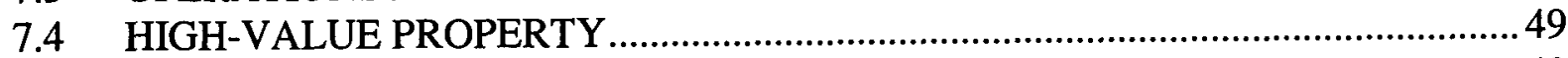

7.5 FIRE HAZARDS.......................................................................................... 49

7.5.1 Waste Emplacement/Retrieval \& Recovery Equipment (Normal Conditions) 50

7.5.1.1 Hazards ............................................................................................... 50

7.5.1.2 Mitigation .............................................................................................5

7.5.2 Waste Recovery \& Restoration Equipment (Abnormal Conditions) .................51

7.5.2.1 Hazards ...........................................................................................5

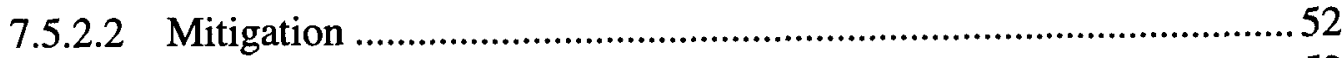

7.5.3 Disposal Containers ................................................................................. 52

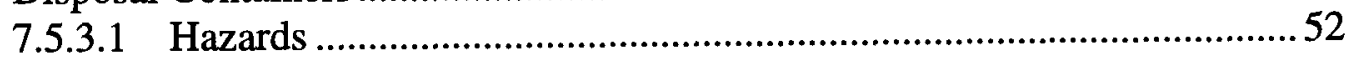

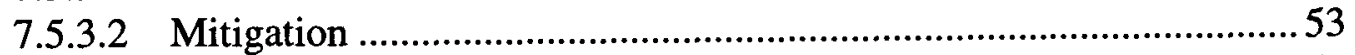

7.5.4 Fixed Electrical Equipment ............................................................................5

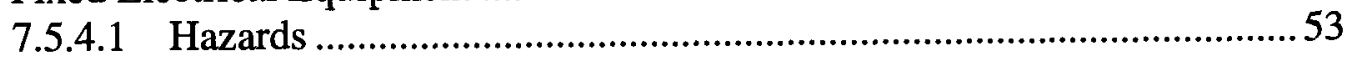

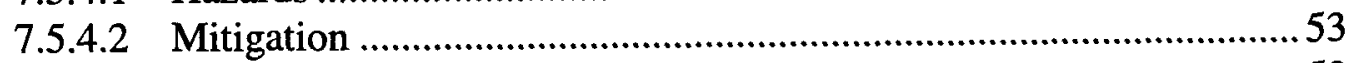

7.5.5 Operations, Monitoring, and Control Systems …………..................................5 53

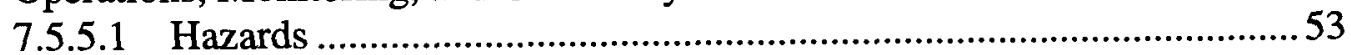

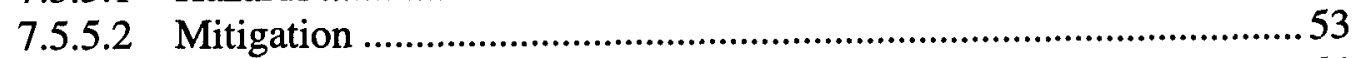

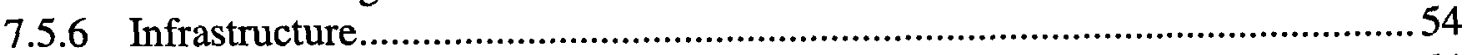

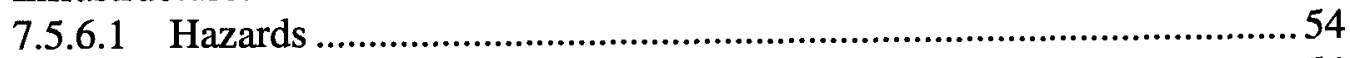

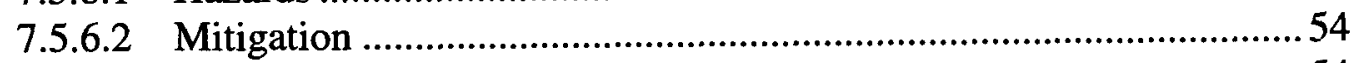

7.5.7 Other ...................................................................................................

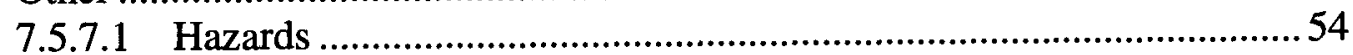

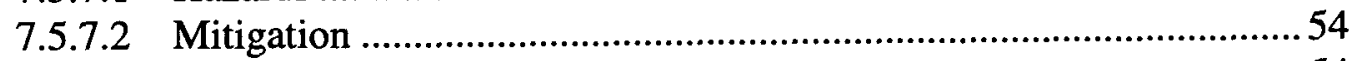

7.5.8 Design Basis Fire ............................................................................................54

7.5.8.1 Design Basis Fire Maximum Possible Fire Loss Estimate .................55

7.5.8.2 Design Basis Fire Mitigation ................................................................5 55

7.6 LIFE-SAFETY CONSIDERATIONS.........................................................................5

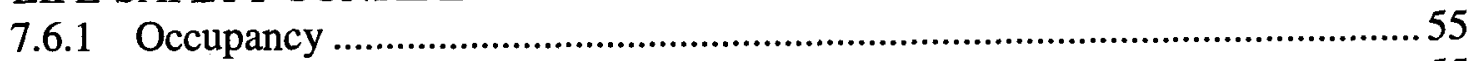

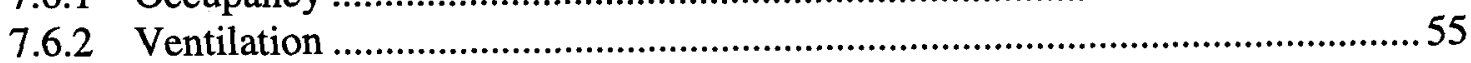

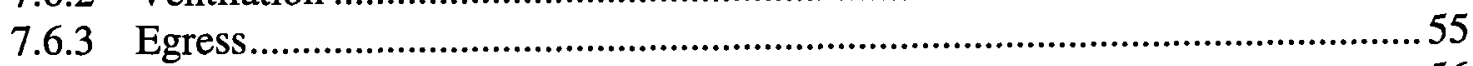

7.6.4 Personal Respiratory Protection .................................................................56

7.6.5 Emergency Refuge Stations...............................................................................56

7.6.6 Alarm/Notification System ................................................................................56

7.6.7 Exit and Emergency Lighting .........................................................................5 56

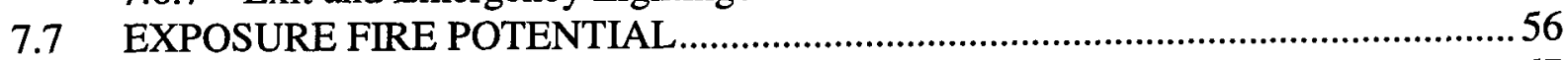

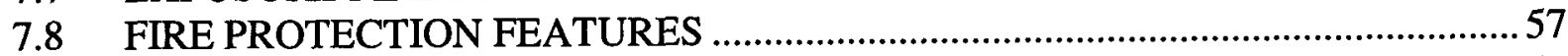



7.8.2 Explosion Prevention....................................................................................... 57 


\section{CONTENTS (Continued)}

Page

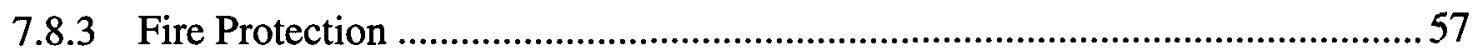

7.9 POTENTIAL FOR A HAZARDOUS INCIDENT …….......................................5

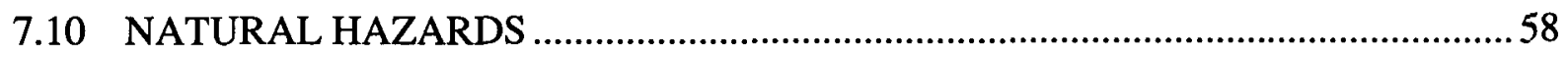

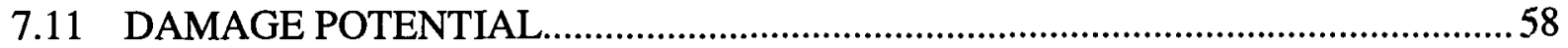

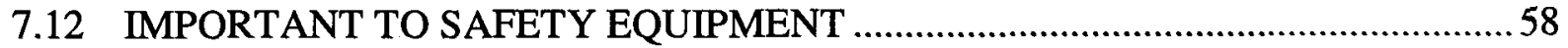

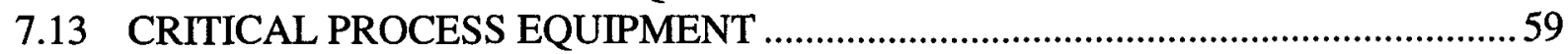

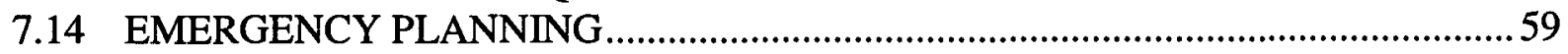

7.15 FIRE DEPARTMENT/BRIGADE RESPONSE....................................................5

7.16 RECOVERY POTENTIAL..................................................................................5

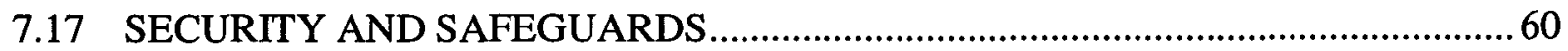



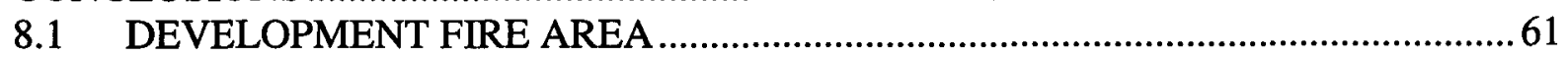

8.1.1 Required Hazard Mitigations..............................................................................61

8.1.2 Items Requiring Further Evaluation/Determination ..........................................62

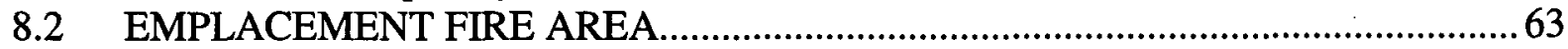

8.2.1 Required Hazard Mitigations..........................................................................63

8.2.2 Items Requiring Further Evaluation/Determination .......................................6 64



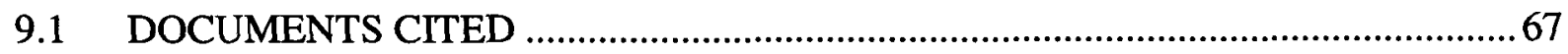

9.2 REGULATIONS, STANDARDS AND DIRECTIVES CITED .................................71

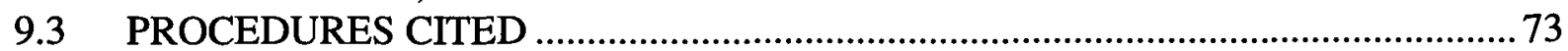

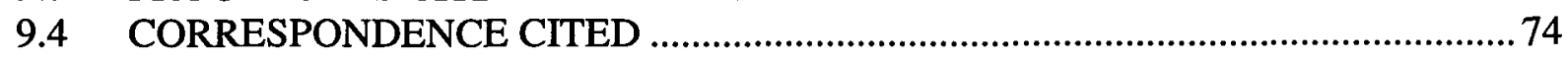






\section{FIGURES}

Page

Figure 1. Subsurface Facility Repository Layout for Site Recommendation ...............................25

Figure 2. Example of Global/Local Ventilation Interaction ......................................................... 27

\section{TABLES}

Page

Table 1. Development Area Quality Assurance Classification Assignment..................................... 4

Table 2. Emplacement Area Quality Assurance Classification Assignment .................................5

Table 3. Development Fire Area Occupancy Classification ..............................................................34

Table 4. Emplacement Fire Area Occupancy Classification........................................................55 
INTENTIONALLY LEFT BLANK 


\section{ACRONYMS AND ABBREVIATIONS}

\section{ACRONYMS}

BSC

CFR

CQ

CRWMS

DBF

DIRS

DOE

ERS

ESF

FCL

FHA

FM

ISM

LAN

$M \& O$

MGR

MPFL

MTHM

NFPA

NRC

OMCS

OSHA

PC

QA

QARD

QL

SCSR

SDD

SNF
Bechtel SAIC Company

Code of Federal Regulations

Conventional Quality

Civilian Radioactive Waste Management System

design basis fire

Document Input Reference System

U.S. Department of Energy

emergency refuge station

Exploratory Studies Facility

functional classification

Fire Hazard Analysis

Factory Mutual

Integrated Safety Management

local area network

Management and Operating Contractor

Monitored Geologic Repository

maximum possible fire loss

metric tons of heavy metal

National Fire Protection Association

U.S. Nuclear Regulatory Commission

operations, monitoring, and control system

Occupational Safety and Health Administration

performance confirmation

quality assurance

Quality Assurance Requirements and Description Quality Level

self-contained, oxygen-generating, self-rescuer

system description document

spent nuclear fuel 
SSC

SSCs

SR

TBD

TBM

TBV

TWP

UL

WHB

WP

YMSCO structure, system or component structures, systems, and components self-rescuer

to be determined

tunnel-boring machine

to be verified

technical work plan

Underwriters Laboratories, Inc.

Waste Handling Building

waste package

Yucca Mountain Site Characterization Office

ABBREVIATIONS

m

meter 


\section{PURPOSE}

This fire hazard analysis identifies preliminary design and operations features, fire, and explosion hazards, and provides a reasonable basis to establish the design requirements of fire protection systems during development and emplacement phases of the subsurface repository.

This document follows the Technical Work Plan (TWP) (CRWMS M\&O 2001c) which was prepared in accordance with AP-2.21Q, Quality Determinations and Planning for Scientific, Engineering, and Regulatory Compliance Activities; Attachment 4 of AP-ESH-008, Hazards Analysis System; and AP-3.11Q, Technical Reports.

\subsection{OBJECTIVE}

The objective of this report is to establish the requirements that provide for facility nuclear safety and a proper level of personnel safety and property protection from the effects of fire and the adverse effects of fire-extinguishing agents.

\subsection{SCOPE}

The scope of this report is to review the subsurface repository facility (for development and emplacement) and its contents in accordance with the appropriate codes, standards, and project documents, including Integrated Safety Management (ISM), to identify fire and adverse effects of fire-extinguishing agents. The report documents preliminary recommendations for mitigating identified fire and adverse effects of fire-extinguishing agents to support development of the design description section of the subsurface fire protection system description document (SDD). The Lower-Temperature Subsurface Layout and Ventilation Concepts analysis (BSC 2001) is used to describe the facility design. Since the repository design is still evolving, the level of detail provided is commensurate with the design information available at the time of preparation of this report.

The determination of specific controls to satisfy ISM requirements cannot be made at this time. Procedure AP-ESH-009, Application of the Grading Approach to Activities Subject to the Integrated Safety Management Quality Assurance Program (ISMQAP) contains a grading process that requires obtaining a functional classification (FCL) from the Safety Basis Report (CRWMS M\&O 2000a). However, the Safety Basis Report does not yet contain any FCLs for repository structures, systems, and components (SSCs). Until the FCLs are determined, the fire protection system will be treated as "Quality" systems for design purposes (CRWMS M\&O 2001c, Section 19).

Subsurface support facilities located at the South Portal, hoist houses, head frames, and fan and filter houses are not included in this technical report evaluation. Further evaluation is needed for these facilities, as design information becomes available. 


\section{INTENTIONALLY LEFT BLANK}




\section{QUALITY ASSURANCE}

This activity has been determined to be quality affecting (CRWMS M\&O 2001c, Addendum D, WP \#12112124MN) since the information in this report affects the design of Quality-Listed items. Therefore, this report is subject to the requirements of the Quality Assurance Requirements and Description (QARD) document (DOE 2000a).

A review of the Quality Assurance (QA) classifications for SSCs in the following analyses, prepared in accordance with project procedure, has been performed and indicates the QA classification assignments presented in Tables 1 and 2.

- Classification of the Monitored Geologic Repository (MGR) Canistered Spent Nuclear Fuel Disposal Container System (CRWMS M\&O 1999a)

- Classification of the MGR Defense High-Level Waste Disposal Container System (CRWMS M\&O 1999b)

- Classification of the MGR DOE Spent Nuclear Fuel Disposal Container System (CRWMS M\&O 1999c)

- Classification of the MGR Emplacement Drift System (CRWMS M\&O 2001a)

- Classification of the MGR Ground Control System (CRWMS M\&O 1999d)

- Classification of the MGR Muck Handling System (CRWMS M\&O 1999e)

- Classification of the MGR Non-Fuel Components Disposal Container System (CRWMS M\&O 1999f)

- Classification of the MGR Operations Monitoring and Control System (CRWMS M\&O 1999g)

- Classification of the MGR Performance Confirmation Emplacement Drift Monitoring System (CRWMS M\&O 1999h)

- Classification of the MGR Performance Confirmation Waste Isolation/Validation System (CRWMS M\&O 1999i)

- Classification of the MGR Subsurface Compressed Air System (CRWMS M\&O 1999j)

- Classification of the MGR Subsurface Closure and Seal System (CRWMS M\&O 1999k)

- Classification of the MGR Subsurface Development Transportation System (CRWMS M\&O 19991) 
- Classification of the MGR Subsurface Electrical Distribution System (CRWMS M\&O 1999m)

- Classification of the MGR Subsurface Excavation System (CRWMS M\&O 1999n)

- Classification of the MGR Subsurface Emplacement Transportation System (CRWMS M\&O 1999o)

- Classification of the MGR Subsurface Fire Protection System (CRWMS M\&O 1999p)

- Classification of the MGR Subsurface Facility System (CRWMS M\&O 1999q)

- Classification of the MGR Subsurface Ventilation System (CRWMS M\&O 1999r)

- Classification of the MGR Subsurface Water Collection/Removal System (CRWMS M\&O 1999s)

- Classification of the MGR Subsurface Water Distribution System (CRWMS M\&O 1999t)

- Classification of the MGR Uncanistered Spent Nuclear Fuel Disposal Container System (CRWMS M\&O 1999u)

- Classification of the MGR Naval Spent Nuclear Fuel Disposal Container System (CRWMS M\&O 1999v)

- Classification of the MGR Waste Emplacement/Retrieval System (CRWMS M\&O 2001b).

Table 1. Development Area Quality Assurance Classification Assignment

\begin{tabular}{|l|l|l|l|}
\hline \multicolumn{1}{|c|}{$\begin{array}{c}\text { MGR Subsurface } \\
\text { System }\end{array}$} & \multicolumn{1}{|c|}{ SSC } & \multicolumn{1}{c|}{ QA Classification } & \multicolumn{1}{c|}{ Reference Citation } \\
\hline Muck Handling System & Muck Handling System & CQ & $\begin{array}{l}\text { CRWMS M\&O 1999e, } \\
\text { Table 1 }\end{array}$ \\
\hline Compressed Air System & Compressed Air System & CQ & $\begin{array}{l}\text { CRWMS M\&O 1999j, } \\
\text { Table 1 }\end{array}$ \\
\hline Transportation System & Transportation System & CQ & $\begin{array}{l}\text { CRWMS M\&O 1999l, } \\
\text { Table 1 }\end{array}$ \\
\hline $\begin{array}{l}\text { Electrical Distribution } \\
\text { System }\end{array}$ & $\begin{array}{l}\text { Electrical Distribution } \\
\text { System }\end{array}$ & CQ & $\begin{array}{l}\text { CRWMS M\&O 1999m, } \\
\text { Table 1 }\end{array}$ \\
\hline Excavation System & Excavation System & CQ & $\begin{array}{l}\text { CRWMS M\&O 1999n, } \\
\text { Table 1 }\end{array}$ \\
\hline Fire Protection System & Fire Protection System & CQ & $\begin{array}{l}\text { CRWMS M\&O 1999p, } \\
\text { Table 1 }\end{array}$ \\
\hline Ventilation System & Ventilation System & CQ & $\begin{array}{l}\text { CRWMS M\&O 1999r, } \\
\text { Table 1 }\end{array}$ \\
\hline $\begin{array}{l}\text { Water Collection/Removal } \\
\text { System }\end{array}$ & $\begin{array}{l}\text { Water Collection/Removal } \\
\text { System }\end{array}$ & CQ & $\begin{array}{l}\text { CRWMS M\&O 1999s, } \\
\text { Table 1 }\end{array}$ \\
\hline Water Distribution System & Water Distribution System & CQ & $\begin{array}{l}\text { CRWMS M\&O 1999t, } \\
\text { Table 1 }\end{array}$ \\
\hline
\end{tabular}


The following classification categories are specified to meet the requirements of the QARD (DOE 2000a) and are defined in the Classification of the MGR Subsurface Fire Protection System (CRWMS M\&O 1999p, Section 6.1) as follows:

- "Quality Level 1 (QL-1) - Those SSCs whose failure could directly result in a condition adversely affecting public safety. These items have a high safety or waste isolation significance.

- Quality Level 2 (QL-2) - Those SSCs whose failure or malfunction could indirectly result in a condition adversely affecting public safety, or whose direct failure would result in consequences in excess of normal operational limits. These items are determined to have low public safety or waste isolation significance.

- Quality Level 3 (QL-3) - Those SSCs whose failure or malfunction would not significantly impact public or worker safety, including those defense-in-depth design features intended to keep doses ALARA (As Low As Reasonably Achievable). These items are determined to have minor impact on public or worker safety or waste isolation.

- Conventional Quality (CQ) - Those SSCs not meeting any of the criteria for Quality Levels 1,2 , or 3. Conventional quality items are not subject to the requirements of QARD."

Table 2. Emplacement Area Quality Assurance Classification Assignment

\begin{tabular}{|c|c|c|c|}
\hline $\begin{array}{l}\text { MGR Subsurface } \\
\text { System }\end{array}$ & SSC & QA Classification & Reference Citation \\
\hline $\begin{array}{l}\text { Canistered Spent Nuclear } \\
\text { Fuel (SNF) Disposal } \\
\text { Container System }\end{array}$ & $\begin{array}{l}\text { Canistered SNF Disposal } \\
\text { Container }\end{array}$ & $\overline{Q L-1}$ & $\begin{array}{l}\text { CRWMS M\&O 1999a, } \\
\text { Table } 1\end{array}$ \\
\hline $\begin{array}{l}\text { Defense High Level Waste } \\
\text { Disposal Container System }\end{array}$ & $\begin{array}{l}\text { Defense High Level Waste } \\
\text { Disposal Container }\end{array}$ & QL-1 & $\begin{array}{l}\text { CRWMS M\&O 1999b, } \\
\text { Table } 1\end{array}$ \\
\hline $\begin{array}{l}\text { DOE SNF Disposal } \\
\text { Container System }\end{array}$ & $\begin{array}{l}\text { DOE SNF Disposal } \\
\text { Container }\end{array}$ & $\overline{Q L-1}$ & $\begin{array}{l}\text { CRWMS M\&O 1999c, } \\
\text { Table } 1\end{array}$ \\
\hline Emplacement Drift System & $\begin{array}{l}\text { Invert: } \\
\text { WP Emplacement Pallet: } \\
\text { Drip Shield: }\end{array}$ & $\begin{array}{l}\text { QL-2 } \\
\mathrm{QL}-2 \\
\mathrm{QL}-1\end{array}$ & $\begin{array}{l}\text { CRWMS M\&O 2001a, } \\
\text { Table } 1\end{array}$ \\
\hline Ground Control System & $\begin{array}{l}\text { Access Mains: } \\
\text { Exhaust Air Mains \& } \\
\text { Raises: } \\
\text { Emplacement Drifts: } \\
\text { Miscellaneous Support } \\
\text { Openings: } \\
\text { Performance Confirmation } \\
\text { Openings: } \\
\text { Portals and Access } \\
\text { Ramps: } \\
\text { Ventilation Shafts: }\end{array}$ & $\begin{array}{l}\mathrm{CQ} \\
\mathrm{CQ} \\
\mathrm{QL}-2 \\
\mathrm{CQ} \\
\mathrm{CQ} \\
\mathrm{CQ} \\
\mathrm{CQ}\end{array}$ & $\begin{array}{l}\text { CRWMS M\&O 1999d, } \\
\text { Table } 1\end{array}$ \\
\hline $\begin{array}{l}\text { Non-Fuel Components } \\
\text { Disposal Container System }\end{array}$ & $\begin{array}{l}\text { Non-Fuel Components } \\
\text { Disposal Container }\end{array}$ & QL-1 & $\begin{array}{l}\text { CRWMS M\&O 1999f, } \\
\text { Table } 1\end{array}$ \\
\hline $\begin{array}{l}\text { Operations Monitoring \& } \\
\text { Control System (OMCS) }\end{array}$ & OMCS & QL-2 & $\begin{array}{l}\text { CRWMS M\&O 1999g, } \\
\text { Table } 1\end{array}$ \\
\hline
\end{tabular}


Table 2 (Continued). Emplacement Area Quality Assurance Classification Assignment

\begin{tabular}{|c|c|c|c|}
\hline $\begin{array}{c}\text { MGR Subsurface } \\
\text { System }\end{array}$ & SSC & QA Classification & Reference Citation \\
\hline $\begin{array}{l}\text { Performance Confirmation } \\
\text { (PC) Emplacement Drift } \\
\text { Monitoring System }\end{array}$ & $\begin{array}{l}\text { Emplacement Drift } \\
\text { Monitoring system: } \\
\text { Inspection Gantry: } \\
\text { Waste Package (WP) } \\
\text { Monitoring System: }\end{array}$ & $\begin{array}{l}\text { QL-3 } \\
\text { QL-3 } \\
\text { QL-3 }\end{array}$ & $\begin{array}{l}\text { CRWMS M\&O 1999h, } \\
\text { Table } 1\end{array}$ \\
\hline $\begin{array}{l}\text { PC Waste Isolation } \\
\text { Verification/Validation } \\
\text { System }\end{array}$ & $\begin{array}{l}\text { PC Waste Isolation } \\
\text { Verification/Validation } \\
\text { System }\end{array}$ & QL-3 & $\begin{array}{l}\text { CRWMS M\&O 1999i, } \\
\text { Table } 1\end{array}$ \\
\hline Compressed Air System & Compressed Air System & $\mathrm{CQ}$ & $\begin{array}{l}\text { CRWMS M\&O 1999j, } \\
\text { Table } 1\end{array}$ \\
\hline Closure \& Seal System & Closure \& Seal System & $C Q$ & $\begin{array}{l}\text { CRWMS M\&O 1999k, } \\
\text { Table } 1\end{array}$ \\
\hline $\begin{array}{l}\text { Electrical Distribution } \\
\text { System }\end{array}$ & $\begin{array}{l}\text { Electrical Distribution } \\
\text { System }\end{array}$ & $C Q$ & $\begin{array}{l}\text { CRWMS M\&O 1999m, } \\
\text { Table } 1\end{array}$ \\
\hline $\begin{array}{l}\text { Emplacement } \\
\text { Transportation System }\end{array}$ & $\begin{array}{l}\text { Emplacement } \\
\text { Transportation System }\end{array}$ & $C Q$ & $\begin{array}{l}\text { CRWMS M\&O 1999o, } \\
\text { Table } 1\end{array}$ \\
\hline Fire Protection System & Fire Protection System & $\mathrm{CQ}$ & $\begin{array}{l}\text { CRWMS M\&O 1999p, } \\
\text { Table } 1\end{array}$ \\
\hline Subsurface Facility System & $\begin{array}{l}\text { Access Mains: } \\
\text { Emplacement Drifts: } \\
\text { Mains \& Raises: } \\
\text { Miscellaneous Support } \\
\text { Openings: } \\
\text { Performance Confirmation } \\
\text { Openings (Test \& } \\
\text { Evaluation Facilities): } \\
\text { Portals and Access } \\
\text { Ramps: } \\
\text { Ventilation Shafts: }\end{array}$ & \begin{tabular}{|l}
$\mathrm{CQ}$ \\
$\mathrm{QL}-1$ \\
$\mathrm{CQ}$ \\
$\mathrm{CQ}$ \\
$\mathrm{CQ}$ \\
$\mathrm{CQ}$ \\
$\mathrm{CQ}$
\end{tabular} & $\begin{array}{l}\text { CRWMS M\&O 1999q, } \\
\text { Table } 1\end{array}$ \\
\hline Ventilation System & Ventilation System & $\mathrm{CQ}$ & $\begin{array}{l}\text { CRWMS M\&O 1999r, } \\
\text { Table } 1\end{array}$ \\
\hline $\begin{array}{l}\text { Water Collection/Removal } \\
\text { System }\end{array}$ & $\begin{array}{l}\text { Water Collection/Removal } \\
\text { System }\end{array}$ & $\mathrm{CQ}$ & $\begin{array}{l}\text { CRWMS M\&O 1999s, } \\
\text { Table } 1\end{array}$ \\
\hline Water Distribution System & Water Distribution System & $\mathrm{CQ}$ & $\begin{array}{l}\text { CRWMS M\&O 1999t, } \\
\text { Table } 1\end{array}$ \\
\hline $\begin{array}{l}\text { Uncanistered SNF } \\
\text { Disposal Container System }\end{array}$ & $\begin{array}{l}\text { Uncanistered SNF } \\
\text { Disposal Container }\end{array}$ & QL-1 & $\begin{array}{l}\text { CRWMS M\&O 1999u, } \\
\text { Table } 1\end{array}$ \\
\hline $\begin{array}{l}\text { Naval SNF Disposal } \\
\text { Container System }\end{array}$ & $\begin{array}{l}\text { Naval SNF Disposal } \\
\text { Container }\end{array}$ & QL-1 & $\begin{array}{l}\text { CRWMS M\&O 1999v, } \\
\text { Table } 1\end{array}$ \\
\hline
\end{tabular}


Table 2 (Continued). Emplacement Area Quality Assurance Classification Assignment

\begin{tabular}{|c|c|c|c|}
\hline $\begin{array}{c}\text { MGR Subsurface } \\
\text { System }\end{array}$ & SSC & QA Classification & Reference Citation \\
\hline $\begin{array}{l}\text { Waste } \\
\text { Emplacement/Retrieval } \\
\text { System } \\
\text { Emplacement, Retrieval, } \\
\text { \& Recovery Systems } \\
\text { (Normal Conditions) }\end{array}$ & $\begin{array}{l}\text { Emplacement Gantry: } \\
\text { Gantry Carrier: } \\
\text { WP Transporter: }\end{array}$ & $\begin{array}{l}\text { QL-3 } \\
\text { CQ } \\
\text { QL-1 }\end{array}$ & $\begin{array}{l}\text { CRWMS M\&O 2001b, } \\
\text { Table } 1\end{array}$ \\
\hline $\begin{array}{l}\text { General Support } \\
\text { Systems }\end{array}$ & $\begin{array}{l}\text { Control and Tracking } \\
\text { System: } \\
\text { Locomotives: } \\
\text { Railcars: }\end{array}$ & $\begin{array}{l}\text { QL-1 } \\
\text { QL-1 } \\
\text { CQ }\end{array}$ & \\
\hline $\begin{array}{l}\text { Recovery Systems } \\
\text { (Abnormal Conditions) }\end{array}$ & $\begin{array}{l}\text { Ball Screw Jack: } \\
\text { Bottom Lift Transporter: } \\
\text { Bottom Lift Transporter } \\
\text { Carrier: } \\
\text { Covered Shuttlecars: } \\
\text { Decontamination } \\
\text { Equipment: } \\
\text { Emplacement Drift Forklift: } \\
\text { Extendable Conveyor: } \\
\text { Load-Haul-Dump Loader: } \\
\text { Main Drift Forklift: } \\
\text { Modified Waste Package } \\
\text { Transporter: } \\
\text { Multi-Purpose Hauler: } \\
\text { Multi-Purpose Vehicle: } \\
\text { Scaling Machine: } \\
\text { Temporary Dock: }\end{array}$ & $\begin{array}{l}\text { CQ } \\
\text { QL-3 } \\
\text { CQ } \\
\text { QL-2 } \\
\text { QL-2 } \\
\text { QL-3 } \\
\text { QL-3 } \\
\text { QL-3 } \\
\text { QL-3 } \\
\text { QL-1 } \\
\text { QL-2 } \\
\text { QL-3 } \\
\text { QL-3 } \\
\text { CQ }\end{array}$ & \\
\hline $\begin{array}{l}\text { Restoration Systems } \\
\text { (Abnormal Conditions) }\end{array}$ & $\begin{array}{l}\text { Cleanup \& Construction } \\
\text { Vehicles: } \\
\text { Emplacement Drift Gantry } \\
\text { Carrier: } \\
\text { Emplacement Drift } \\
\text { Restoration Locomotive: } \\
\text { Re-Railer: } \\
\end{array}$ & $\begin{array}{l}\mathrm{CQ} \\
\mathrm{QL-3} \\
\mathrm{QL-3} \\
\mathrm{CQ}\end{array}$ & \\
\hline
\end{tabular}

The results from this report are preliminary and will not be used directly for procurement, fabrication, or construction. 
INTENTIONALLY LEFT BLANK 


\section{COMPUTER SOFTWARE}

This report uses commercial off-the-shelf software in its preparation. No software routines or models are used and no calculations are performed.

No controls are required for the management of electronic data transfer for this report (CRWMS M\&O 2001c, Addendum D, Section 10). 
INTENTIONALLY LEFT BLANK 


\section{INPUTS}

This section identifies and documents all technical product inputs and sources of input that are used in the development of this technical report. The qualification status of the input is indicated in the DIRS database, as well as the documentation for those to be verified (TBV) or to be determined (TBD), in accordance with AP-3.15Q, Managing Technical Product Inputs.

A search for relevant off-project (non-CRWMS) literature (AP-3.11Q, Section $5.2 \mathrm{f}$ ) was made but none are identified, other than National Fire Protection Association (NFPA) codes and standards and U.S. Nuclear Regulatory Commission (NRC) regulations. In addition to the codes and standards specifically cited throughout this report, the following NFPA codes and standards were reviewed for information pertinent to the subsurface repository preliminary design. No information was identified for incorporation into this report.

- NFPA 101, Life Safety Code.

- NFPA 130, Standard for Fixed Guideway Transit and Passenger Rail Systems.

- NFPA 241, Standard for Safeguarding Construction, Alteration, and Demolition Operations.

- NFPA 502, Standard for Road Tunnels, Bridges, and Other Limited Access Highways.

- NFPA 520, Standard on Subterranean Spaces.

The following NRC documents were reviewed for information pertinent to the subsurface repository preliminary design. Although only one NRC regulation is specifically cited in this report (Criterion 4.2.5.1), the preliminary fire protection design complies with these regulations. In general, the generic NRC fire protection requirements/guidance refers the designer back to codes and standards, such as those established by the NFPA, which are cited throughout this report.

- "Fire Protection Program." Section 9.5.1 of Standard Review Plan for the Review of Safety Analysis Reports for Nuclear Power Plants. LWR Edition. NUREG-0800, Rev 3. (NRC 1981)

- Fire Protection for Operating Nuclear Power Plants-Regulatory Guide 1.189 (Regulatory Guide 1.189. 2001)

The Yucca Mountain Project's “OCRWM (Office of Civilian Radioactive Waste Management) Lesson Learned Program" database (DOE 2001) was reviewed for applicable information (AP-ESH-008, Section 5.1.1.4.b). No applicable information was found for incorporation into this report. 


\subsection{PARAMETERS}

Not used.

\subsection{CRITERIA}

Criteria include the requirements contained in the applicable requirements documents that are identified as specific to the subject of this report. The criteria statements in Sections 4.2.1, 4.2.2, 4.2.3, 4.2.4, 4.2.5 and 4.2.7 are contained in the:

- Subsurface Fire Protection System Description Document [(CRWMS M\&O 1999w) Assumption 5.3]

- Subsurface Facility System Description Document (CRWMS M\&O 2000b)

- Subsurface Ventilation System Description Document (CRWMS M\&O 2000c).

- Subsurface Electrical Distribution System Description Document [(CRWMS M\&O 1999x) Assumption 5.3]

- "Fire Protection Program." Section 9.5.1 of Standard Review Plan for the Review of Safety Analysis Reports for Nuclear Power Plants. LWR Edition. NUREG-0800, Rev 3. (NRC 1981)

The criteria used as input requirements to this technical report are not considered TBV.

\subsubsection{Design Basis}

\subsubsection{Fire Protection Functions}

The fire protection system provides the means to control, prevent propagation, and extinguish subsurface fires (CRWMS M\&O 1999w, Section 1.1.2). [This criterion is used in Section 6.8 of this report].

\subsubsection{System Performance}

\subsubsection{System Design}

The system shall be designed to protect against the fire related hazards and occupancy classifications of the subsurface areas as delineated in Table 1-1 of the Subsurface Fire Protection System Description Document (CRWMS M\&O 1999w, Section 1.2.1.1). [This criterion is used in Sections 6.6.1 and 7.6.1 of this report]. 


\subsubsection{Automatic Fire Extinguishing}

The system shall provide automatic fire suppression in areas where the maximum possible fire loss (MPFL) exceeds $\$ 1$ million (CRWMS M\&O 1999w, Section 1.2.1.2). [This criterion is used in Section 6.11 of this report].

\subsubsection{Redundant Fire Protection}

The system shall provide redundant fire protection in areas where the MPFL exceeds $\$ 50$ million (CRWMS M\&O 1999w, Section 1.2.1.3). [This criterion is used in Sections 6.5.6.2 and 6.11 of this report].

\subsubsection{Non-Monitored Geologic Repository Fire Response}

The system shall provide an adequate level of fire protection without relying on non-MGR fire response organizations (CRWMS M\&O 1999w, Section 1.2.1.4). [This criterion is used in Section 7.15 of this report].

\subsubsection{Safety Criteria}

\subsubsection{Primary and Backup Fire Protection}

The system shall provide primary and backup fire protection in the subsurface areas where important-to-radiological-safety equipment are vulnerable to credible fire and explosion hazards (CRWMS M\&O 1999w, Section 1.2.2.1.1). [This criterion is used in Sections 7.5.1.2 and 6.8.3 of this report].

\subsubsection{Component Failure}

The system shall be designed so that a single failure of any one component (equipment or control device) will not disable the entire fire detection, alarm, and suppression capabilities (CRWMS M\&O 1999w, Section 1.2.2.1.2). [This criterion is used in Section 6.8.3 of this report].

\subsubsection{Effects of Credible Fires and Explosions}

The system shall be designed so that the effects of credible fires and explosions do not spread throughout the subsurface facility (CRWMS M\&O 1999w, Section 1.2.2.1.3). [This criterion is used in Sections 6.2.3, 6.11, and 7.8.3 of this report].

\subsubsection{Fire Protection Actuation or Failure}

The system shall be designed so actuation or failure of the fire protection SSCs will not cause adverse effects to subsurface nuclear safety related equipment (i.e., cause them to become disabled (CRWMS M\&O 1999w, Section 1.2.2.1.4). [This criterion is used in Section 7.5.1.2 of this report]. 


\subsubsection{Fire Alarms}

The system shall provide zoned audible and visual fire alarm annunciation in the affected areas (CRWMS M\&O 1999w, Section 1.2.2.2.1). [This criterion is used in Sections 6.6.6, 6.8.3.6, 6.8.3.7, and 7.6.6 of this report].

\subsubsection{Fire Detection}

The system shall provide manual and automatic means of fire detection for subsurface fires (CRWMS M\&O 1999w, Section 1.2.2.2.2). [This criterion is used in Sections 6.6.6, 6.8.3.7 and 7.6.6 of this report].

\subsubsection{Smoke Removal/Containment}

The system shall locate fire or smoke detectors, with consideration of subsurface physical factors, to ensure early detection and smoke removal or containment (CRWMS M\&O 1999w, Section 1.2.2.2.3). [This criterion is used in Sections 6.6.2, 6.6.3.4, 7.6.2, and 7.8.3 of this report].

\subsubsection{System Approval and Listing}

The system components shall be Underwriters Laboratories, Inc. (UL) and/or Factory Mutual (FM) approved/listed for use in fire protection systems (CRWMS M\&O 1999w, Section 1.2.2.2.6). [This criterion is used in Section 6.8.3.9 of this report].

\subsubsection{Emergency Refuge Stations}

A method of refuge shall be provided for employees who cannot reach the surface from their workplace, through at least two separate escapeways, within a time limit of one hour when using the normal exit method (i.e., walking). These refuges must be positioned so that the employee can reach one of them within 30 minutes from the time the workplace is left (CRWMS M\&O 2000b, Section 1.2.2.2.2). [This criterion is used in Sections 6.6.4 and 6.6.5 of this report].

\subsubsection{Egress Travel Time}

Travel times for exiting or reaching a refuge shall be based on a maximum rate for personnel travel of $2,100 \mathrm{~m}$ in 30 minutes (CRWMS M\&O 2000b, Section 1.2.2.2.3). [This criterion is used in Sections 6.6.4 and 6.6.5 of this report].

\subsubsection{Electrical Distribution Safety Criteria}

\subsubsection{Transformer Design}

The subsurface electrical distribution transformers shall be of the dry type (CRWMS M\&O 1999x, Section 1.2.1.9). [This criterion is used in Sections 6.5.1.2, 6.5.2.2 and 6.8.1.2 of this report]. 


\subsubsection{Materials}

The system design shall incorporate use of noncombustible and heat resistant materials (CRWMS M\&O 1999x, Section 1.2.1.11). [This criterion is used in Sections 6.5.1.2, 6.5.2.2 and 7.5.4.2 of this report].

\subsubsection{National Codes}

The system shall be designed to meet the nationally recognized electrical codes and standards (CRWMS M\&O 1999x, Section 1.2.6). [This criterion is used in Section 7.5 of this report].

\subsubsection{Lightning Protection}

The system shall be designed in accordance with the applicable sections of NFPA 780 (CRWMS M\&O 1999w, Section 1.2.6.16; CRWMS M\&O 1999x, Section 1.2.6.7). [This criterion is used in Section 6.10 of this report].

\subsubsection{Guidance from U.S. Nuclear Regulatory Commission Regulatory Guidance Documents}

\subsubsection{Facility Fire Brigade}

A facility fire brigade trained and equipped for firefighting should be established to ensure adequate manual firefighting capability for all areas of the facility containing SSCs important to radiological safety (NRC 1981, Section C.3.b). [This criterion is used in Section 7.15 of this report].

\subsubsection{Control Systems}

\subsubsection{Safety and Monitoring Systems}

The operations, monitoring, and control system (OMCS) will use fiber distributed data interface local area networks (LANs) (CRWMS M\&O 2000d, Section 6.3.4). The fiber distributed data interface backbone will be a dual-ring network (two cables, two fibers per cable) comprising a number of distributed nodes linking area-specific Ethernet and specialty LANs, which, in turn, are connected to subsurface processes regarded as critical to safety. All links to the Ethernet LANs will be doubly redundant (four circuits).

The Subsurface Repository Integrated Control System Design Analysis (CRWMS M\&O 2000d) presents preliminary conceptual designs for the instrument and control systems. Since these systems have been classified as QL-2 systems (See Table 2), and the routing of the fiber networks is not determined, this design input requires confirmation. Since there is uncertainty as to the actual routing throughout the repository, the monitoring systems are not included in Table 1 for the development area. [This criterion is used in Section 7.5.5.2 of this report]. 


\subsubsection{Ventilation System}

\subsubsection{Fresh Air Supply}

The system shall provide a minimum quantity of fresh air (surface ambient) to accommodate a maximum of 353 persons on the development side and a maximum of 89 persons on the emplacement side (CRWMS M\&O 2000c, Section 1.2.1.1). [This criterion is used in Sections 6.6.2 and 7.6.2].

\subsubsection{Ventilation Separation}

The system shall provide ventilation for the development and emplacement areas by two separate and independent systems (CRWMS M\&O 2000c, Section 1.2.1.6). [This criterion is used in Sections 6.2.2, 6.7, and 7.7].

\subsubsection{Standards}

\subsubsection{Occupational Safety and Health Standards}

The system shall comply with the applicable provisions of 29 CFR (Code of Federal Regulations) 1910 (CRWMS M\&O 1999w, Section 1.2.6.1). [This criterion is used in Sections 6.14 and 7.6.7 of this report].

\subsubsection{Safety and Health Regulations for Construction}

The system shall be designed so that its construction complies with the applicable provisions of 29 CFR 1926 (CRWMS M\&O 1999w, Section 1.2.6.2). [This criterion is used in Sections 6.5.2.2, $6.6 .7,6.7,6.8 .1 .1,6.8 .1 .3,6.8 .3 .6$, and 7.7 of this report].

\subsubsection{U.S. Department of Energy Orders}

Fire Protection design shall comply with DOE Order 420.1 (CRWMS M\&O 1999w, Section 1.2.6.3). [This criterion is used in Sections 6.1 and 6.11 of this report].

\subsubsection{U.S. Department of Energy Implementation Guidance}

Fire protection design shall comply with DOE Implementation Guide (DOE G 440.1-5) for use with DOE Order 420.1 (CRWMS M\&O 1999w, Section 1.2.6.3). [This criterion is used in Sections 6.1, 6.2.3, and 6.4 of this report]. 


\subsubsection{Sprinkler Systems}

The portion of the system that relies on water sprinklers shall comply with NFPA 13, Standard for the Installation of Sprinkler Systems-1999 Edition, as applicable to the design (CRWMS M\&O 1999w, Section 1.2.6.4). [This criterion is used in Sections 6.6.1 and 7.6.1 of this report].

\subsubsection{Fire Alarm Systems}

The system shall comply with NFPA 72, National Fire Alarm Code - 1999 Edition, as applicable to detection design (CRWMS M\&O 1999w, Section 1.2.6.5). [This criterion is used in Sections 6.6.6, 6.8.3.7, 7.6.6, and 7.8.3 of this report].

\subsubsection{Fire Mains}

The system shall comply with NFPA 24, Standard for the Installation of Private Service Fire Mains and Their Appurtenances-1995 Edition, as applicable to service main design (CRWMS M\&O 1999w, Section 1.2.6.6). [This criterion is used in Section 6.8.3.5 of this report].

\subsubsection{Standpipe and Hose Systems}

The system shall comply with NFPA 14, Standard for the Installation of Standpipe and Hose Systems - 2000 Edition, as applicable to standpipe and hose station design (CRWMS M\&O 1999w, Section 1.2.6.7). [This criterion is used in Section 6.8.3.9 of this report].

\subsubsection{Portable Fire Extinguishers}

The system shall comply with NFPA 10, Standard for Portable Fire Extinguishers - 1998 Edition, as applicable (CRWMS M\&O 1999w, Section 1.2.6.8). [This criterion is used in Sections 6.8.3.5, and 6.8.3.8 of this report].

\subsubsection{Facilities Handling Radioactive Materials}

The system shall comply with NFPA 801, Standard for Fire Protection for Facilities Handling Radioactive Materials - 1998 Edition (CRWMS M\&O 1999w, Section 1.2.6.9). [This criterion is used in Section 7.5.7.2 of this report]. 


\subsection{CODES AND STANDARDS}

This section lists the codes and standards directly used in this technical report.

\subsubsection{Code of Federal Regulations}

\subsubsection{Energy}

10 CFR 71. Energy: Packaging and Transportation of Radioactive Material. January 1, 2001.

\subsubsection{Occupational Safety \& Health Standards}

29 CFR 1910. Labor: Occupational Safety \& Health Standards. July 1, 1998.

\subsubsection{Safety and Health Regulations for Construction}

29 CFR 1926. Labor: Safety and Health Regulations for Construction. July 1, 1998.

\subsubsection{Safety and Health Standards--Underground Metal and Nonmetal Mines}

30 CFR 57. Mineral Resources: Safety and Health Standards--Underground Metal and Nonmetal Mines. July 1, 1999.

\subsubsection{U.S. Department of Energy Orders}

\subsubsection{Facility Safety}

DOE Order 420.1. Facility Safety. 1995, Change 3, 11-22-00.

NOTE: For requirements governed by both the NRC and DOE Order 420.1, NRC requirements take precedence (DOE Order 420.1, Paragraph 3c).

\subsubsection{Design Implementation}

DOE G 440.1-5. Implementation Guide for use with DOE Orders 420.1 and 440.1, Fire Safety Program. September 30, 1995.

\subsubsection{National Fire Protection Association}

\subsubsection{Portable Fire Extinguishers}

NFPA 10. Standard for Portable Fire Extinguishers - 1998 Edition. 


\subsubsection{Sprinkler Systems}

NFPA 13. Standard for the Installation of Sprinkler Systems - 1999 Edition.

\subsubsection{Standpipe and Hose Systems}

NFPA 14. Standard for the Installation of Standpipe and Hose Systems - 2000 Edition.

\subsubsection{Dry Chemicals}

NFPA 17. Standard for Dry Chemical Extinguishing Systems - 1998 Edition.

\subsubsection{Fire Mains}

NFPA 24. Standard for the Installation of Private Service Fire Mains and Their Appurtenances - 1995 Edition.

\subsubsection{Flammable and Combustible Liquids}

NFPA 30. Flammable and Combustible Liquids Code - 2000 Edition.

\subsubsection{Hot Work}

NFPA 51B. Standard for Fire Prevention During Welding, Cutting and Other Hot Work - 1999 Edition.

\subsubsection{National Electrical Code}

NFPA 70. National Electrical Code - 1999 Edition.

\subsubsection{National Fire Alarm Code}

NFPA 72. National Fire Alarm Code - 1999 Edition.

\subsubsection{Underground Mines}

NFPA 122. Standard for Fire Prevention and Control in Underground Metal and Non-Metal Mines - 2000 Edition.

\subsubsection{Tank Vehicle Design}

NFPA 385. Standard for Tank Vehicles for Flammable and Combustible Liquids - 2000 Edition 


\subsubsection{Lightning Protection}

NFPA 780. Standard for the Installation of Lightning Protection Systems - 1997 Edition.

\subsubsection{Facilities Handling Radioactive Materials}

NFPA 801. Standard for Fire Protection for Facilities Handling Radioactive Materials - 1998 Edition.

\subsubsection{Clean Agent Fire Extinguishing Systems}

NFPA 2001. Standard on Clean Agent Fire Extinguishing Systems - 2000 Edition. 


\section{ASSUMPTIONS}

The following assumptions are used in this report. Assumption 5.1 applies to the development phase only. Assumptions 5.2 and 5.3 apply to development and emplacement phases of the repository.

The determination whether to track these assumptions is made using the input status decision checklist in AP-3.15Q, Managing Technical Product Inputs. All the assumptions are considered as "No Confirmation Required" and are not controlled as TBV information. The judgement used to determine each assumption's status is documented in the justification statement.

\subsection{EXPLORATORY STUDIES FACILITY FIRE HAZARD ANALYSIS}

Assumption: The construction and development phase hazards for the subsurface facilities are similar to those identified in the fire hazard evaluation performed for the Exploratory Studies Facility (ESF). [This assumption is used throughout Section 6 of this report].

Justification: The construction activities in the development phase will be similar to those used to construct the ESF and the fire hazards will be the same. The fire hazard evaluations (CRWMS M\&O 1994, CRWMS M\&O 1998a) are approved, project specific engineering studies, therefore, the use of the input will not be controlled as TBV information.

Note that the MPFL estimate cited in Section 6.5.6.1 is contained in the Subsurface Fire Hazards Analysis (CRWMS M\&O 1994, Attachment II). The current revision of this document is 01 but this cannot be referenced since this estimate was not carried forward into revision 01 .

\subsection{MAXIMUM POSSIBLE FIRE LOSS}

Assumption: The worst-case fire scenario is a single fire in one fire area without any other concurrent accidents or abnormal system alignments. [This assumption is used in Section 6.5.6 of this report].

Justification: It is unlikely that two or more concurrent events would occur and such an occurrence would impose unnecessary design restrictions. The use of this input will not be controlled as TBV information.

\subsection{REQUIREMENTS DOCUMENTS}

The following system description documents require revision to comply with current federal requirements and project procedures:

- Subsurface Fire Protection System Description Document (CRWMS M\&O 1999w) [Criteria used in Section 4.2 of this report].

- Subsurface Electrical Distribution System Description Document (CRWMS M\&O 1999x) [Criteria used in Section 4.2 of this report]. 
- Safeguards and Security System Description Document (CRWMS M\&O 1999z). [Used in Section 7.17 of this report].

Assumption: The design requirements, taken from these documents, will continue to provide the basis for the fire protection design in the repository.

Justification:

- The majority of requirements statements will be carried forward into document revisions.

- The TWP (CRWMS M\&O 2001c, Section 5) specifies that "the Fire Protection SDD (CRWMS M\&O 1999w) will be used as a basis for some design inputs."

- Addendum D, Section 5 of the TWP (CRWMS M\&O 2001c) specifies that "the Electrical Distribution (CRWMS M\&O 1999x) and Safeguards and Security (CRWMS M\&O 1999z) SDDs will be used as a basis for design inputs."

- Adjustments and changes that are made are not expected to change the conclusions of this report and will not be controlled as TBV information. 


\section{DEVELOPMENT FIRE AREA HAZARDS}

\subsection{INTRODUCTION}

Many design criteria guidance documents are used for identifying, assessing, and recommending appropriate mitigation for fire protection systems that are necessary to perform the repository design. Design criteria guidance documents used in developing this report include references to engineering design codes and standards; orders, laws and regulations; CRWMS M\&O documents regarding repository design requirements; and industry codes, standards and practices. The documents are reviewed; the applicable information is extracted, and included in this technical report to form a basis for fire protection system design requirements that need to be addressed in the subsurface repository design.

The FHA elements used in this report are outlined in the Implementation Guide [(Criterion 4.2.8.4) DOE G 440.1-5, Section IV, Paragraph 4.5]. While this report presents all of the required elements, it does not follow the identical sequence outlined in the Implementation Guide.

Conclusions and requirements for hazard mitigation are presented, which when incorporated into the fire protection systems design, will enable the program objectives required by the NRC (Dyer 1999), and Order 420.1 [(Criterion 4.2.8.3) DOE Order 420.1, Section 4.2] to be met.

\subsection{CONSTRUCTION}

\subsubsection{Major Design Elements}

A subsurface facility repository layout has been developed (BSC 2001, Figure 3) to support the lower-temperature operating mode concept for the Site Recommendation design that is capable of accommodating 70,000 metric tons of heavy metal (MTHM), as well as the option to expand the capacity to 97,000 MTHM, if authorized. Figure 1 shows the repository layout.

The major design elements of the repository include the primary-block and the optional lower-block, and two existing entries (See Figure 1), the North Ramp and the South Ramp, that access the subsurface repository host horizon. The ramps are joined together by the excavated portion of the East Main. This existing excavation provides the platform to initiate further excavation.

\subsubsection{70,000 Metric Ton Case Layout}

In the Site Recommendation design (Figure 1), further excavation of the primary-block includes the $7.62 \mathrm{~m}$ (25 feet) diameter (BSC 2001, Section 6.1.2.1.1) perimeter main drift. This is comprised of two, approximately parallel drifts that are oriented North to South, about 1000 meters apart over a distance of about 5000 meters. They are joined into a circuit around the emplacement area by east to west drifts at each end. Inside the perimeter, $5.5 \mathrm{~m}$ (18 feet) diameter (BSC 2001, Section 6.1.2.1.2) emplacement drifts are excavated from the east main to the west main in parallel alignment. 
Above the repository horizon, bisecting the emplacement drift alignment, is a single $7.62 \mathrm{~m}$ ( 25 feet) diameter (BSC 2001, Table 17) exhaust main with an internal partition to separate service and construction/emplacement exhaust air. The main runs from the South end of the repository to the North end of the repository. Each emplacement drift has one ventilation raise to the exhaust side of the main.

Eleven shafts are required for the primary-block repository layout (See Figure 1). Five shafts are used to bring intake air into the repository along with the access ramps. Six additional shafts are used to exhaust air from the repository. The development shaft provides intake air during development and construction operations and will be converted to an intake shaft for emplacement operations. Hoist houses, head frames, and fan and filter houses are located on the surface at the top of the shafts.

There will be two standby and four cross-block drifts in the emplacement area (See Figure 1). The cross-block drifts facilitate ventilation and emergency egress. The standby drifts are left empty and available for temporary relocation of WPs, if necessary.

Five observation/post-closure test drifts are incorporated into the layout (See Figure 1). Four observation drifts are located below the repository horizon and a post-closure drift in the repository horizon. In addition, the repository design includes ancillary development such as drifts that connect the shafts to the main body of the repository.

The emplacement area will occupy the majority of the primary-block ( 85 emplacement drifts) (BSC 2001, Section 6.1.3). The total emplacement length, including allowances, is approximately 81 kilometers (50 miles) (BSC 2001, Section 6.1.3).

\subsubsection{97,000 Metric Ton Case Layout}

In the Site Recommendation design (Figure 1), excavation of the lower-block includes the $7.62 \mathrm{~m}$ (25 feet) diameter (BSC 2001, Section 6.1.2.1.1) perimeter main drift and access ramps. Inside the perimeter, $5.5 \mathrm{~m}$ (18 feet) diameter (BSC 2001, Section 6.1.2.1.2) emplacement drifts are excavated from the east main to the west main in parallel alignment.

Fifteen shafts are required for the 97,000 MTHM repository layout (See Figure 1). Seven shafts are used to bring intake air into the repository along with the access ramps. Eight additional shafts are used to exhaust air from the repository. One of the intake shafts and two of the exhaust shafts are located in the lower-block. The development shaft will be converted to an intake shaft for emplacement operations. Hoist houses, head frames, and fan and filter houses are located on the surface at the top of the shafts.

There will be three standby and five cross-block drifts in the emplacement area (See Figure 1). The cross-block drifts facilitate ventilation and emergency egress. The standby drifts are left empty and available for temporary relocation of WPs, if necessary. 


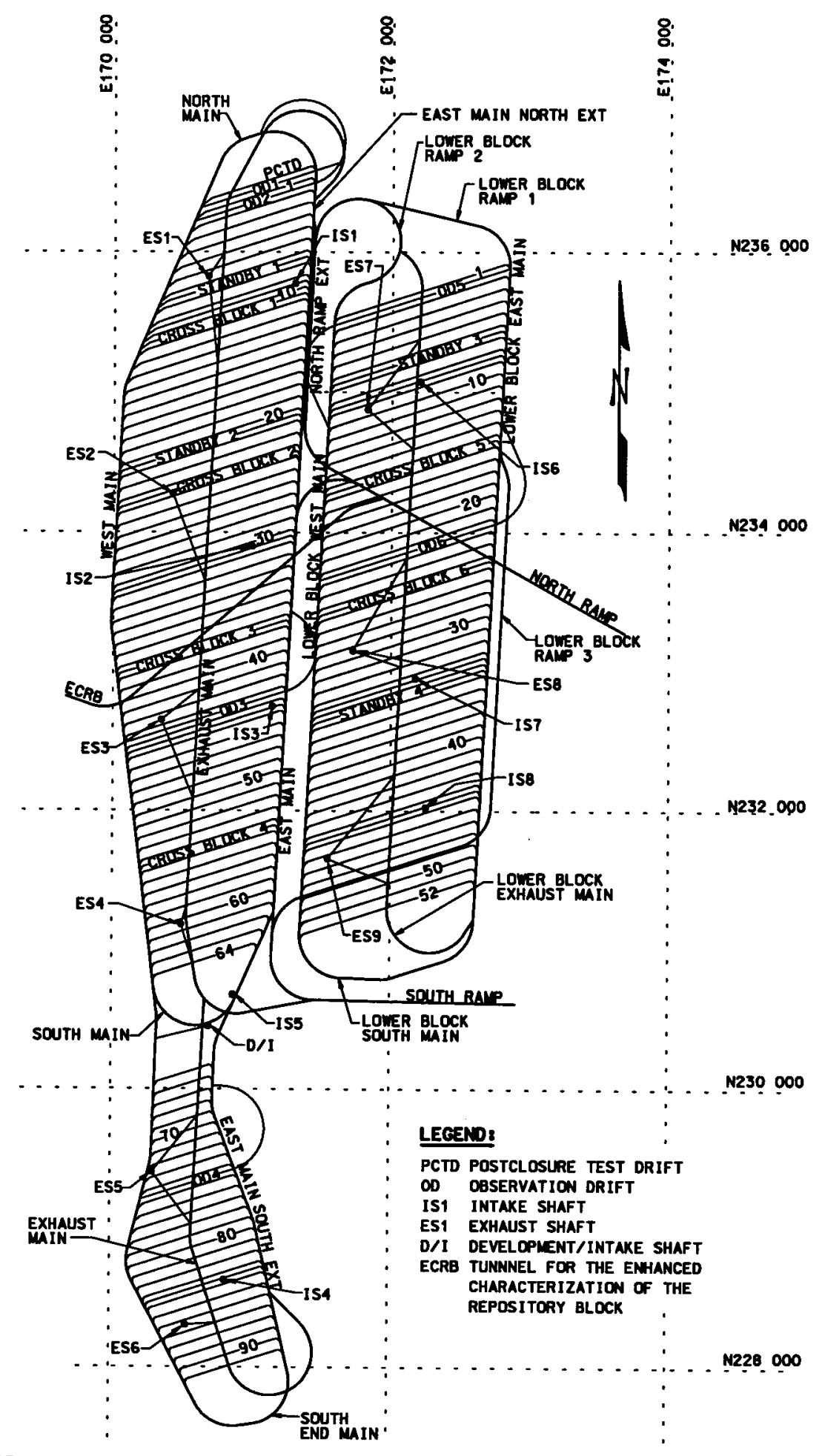

MOTES:

1. DINENSIONS, COORDINATES. aNd ELEVATIONS ARE

2. MOATHING AND EASTING VALUES ARE NEVADA STATE PLAN CAO FILEstob_-01_lt_-oeneria.fio
SCALE: NONE

Source: BSC 2001, Figure 3

Figure 1. Subsurface Facility Repository Layout for Site Recommendation 
Five observation drifts are located below the repository horizon and a post-closure drift is located in the repository horizon (See Figure 1). One of the observation drifts is located in the lower-block. In addition, the repository design includes ancillary development such as drifts that connect the shafts to the main body of the repository.

The emplacement area will occupy all of the primary-block and a portion of the lower-block (for a total of 110 emplacement drifts) (BSC 2001, Section 6.1.4). The total emplacement length, including allowances, is approximately 107 kilometers (67 miles) (BSC 2001, Section 6.1.4).

\subsubsection{Repository Construction Evolution}

Repository construction can be described by two main phases. The first phase, the development phase, occurs when only the construction of the repository is taking place. The development phase consists of two elements. One, the initial excavation of the drifts and two, the construction of the infrastructure required preparing for emplacement operations. The second phase, the emplacement phase, occurs when waste emplacement begins and the repository construction is still in progress. A distinguishing design feature between the two phases is the ventilation system. During development, a single ventilation system services the repository. During combined emplacement and development, two, separate ventilation systems are in use. Each ventilation system operates independently of the other (Criterion 4.2.7.2). One ventilation system services the emplacement side of the repository and one services the development side of the repository. Physical barriers are erected between the two sides to prevent the mixing of the air streams.

\subsubsection{Fire Boundaries}

Fire boundaries are a function of the subsurface repository construction chronology. Initially, the repository is one fire area, based on the DOE definition of Fire Area [(Criterion 4.2.8.4) DOE G 440.1-5. 1995, Section IV, Paragraph 4.9]. This is during the development phase. When waste emplacement begins, there are two fire areas. One is the Development Fire Area described here in Section 6 of this report, the other is the Emplacement Fire Area described in Section 7 of this report. These two fire areas will be physically separated by ventilation barriers. Finally, after completion of development, the repository reverts to one fire area after the ventilation barriers are removed.

A fire area is defined as: "a location bounded by fire-rated construction, having a minimum fire resistance rating of 2 hours, with openings protected by equivalently-rated fire doors, dampers or penetration seals" [(Criterion 4.2.8.4) DOE G 440.1-5. 1995, Section IV, Paragraph 4.9].

Consequently the ventilation barriers at the development/emplacement fire areas interface will require a minimum fire resistance rating of 2 hours (Criterion 4.2.3.3) with equivalently rated openings, dampers and penetration seals. The development and emplacement fire areas will be considered as separate and distinct fire areas. The effects of fire contamination from one fire area to the other are adequately addressed by the barrier design constraints. 


\subsubsection{Ventilation System Concept}

The development ventilation concept is described and defined as being in two parts in the Ventilation Needs During Construction analysis (CRWMS M\&O 1998b, Section 3). One part is global ventilation and the other is local ventilation. Global ventilation is defined as the ventilation system provided in the main drifts. An example of global ventilation is the system between an emplacement drift/main drift intersection and the surface. Local ventilation is defined as the ventilation system provided from the main drift through the working drift to the working face. The working face is where a mechanical excavator is extending the length of a drift that is a dead-end heading. An example of local ventilation is the system between a tunnel-boring machine (TBM) excavating an emplacement drift and the intersection of that emplacement drift and the main drift. Excavation methods can be either mechanical (TBM) or conventional (drill and blast). Figure 2 shows an example of the interaction between global and local ventilation systems using the ESF as a flow-through system.

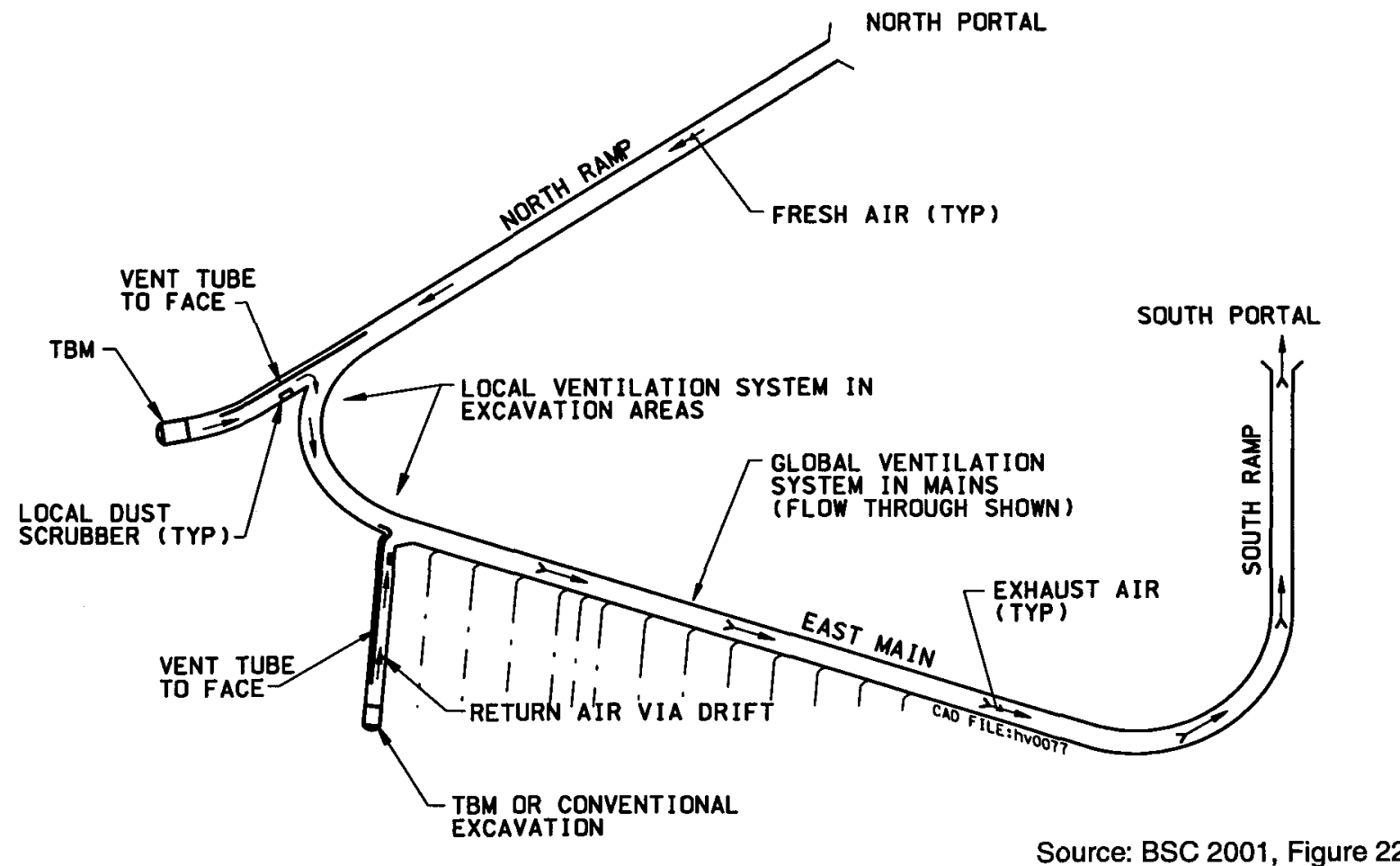

Figure 2. Example of Global/Local Ventilation Interaction

In this example, the local ventilation system intakes fresh air from the ESF, uses it at the working face, filters it as necessary and then discharges it back toward the ESF South Ramp or ducts it to the surface.

The Ventilation Needs During Construction analysis (CRWMS M\&O 1998b, Section 8) concluded that the best ventilation system (global and local combined) was Option C/Alternative 2, because it provided the best rating per the cited analysis evaluation for fire hazards (CRWMS M\&O 1998b, Table 7-8). Option C (global) is described as a ducted exhaust system (CRWMS M\&O 1998b, 
Section 7.1) where intake air is supplied through the main drift from the surface to the entrance of the working drift and is exhausted by duct back to the surface. The system is similar to that used to excavate the ESF. Alternative 2 (local) intakes air from the main drift through the working drift to the working face (CRWMS M\&O 1998b, Section 7.3.2). All the air passes through the working face, is scrubbed, and then flows into a duct. The entire exhaust air flows through the duct away from the working face back to the main drift.

\subsection{OPERATIONS}

During the development phase, the only subsurface operations are excavation of the main and emplacement drifts, and installation of the emplacement area infrastructure, such as ventilation barriers, ventilation system, power systems, and control and monitoring systems.

\subsection{HIGH-VALUE PROPERTY}

High-value property is presented here to identify construction equipment that requires fire protection and has a potential MPFL greater than $\$ 1$ million [(Criterion 4.2.8.4) DOE G 440.1-5, Section IV, Paragraph 9.7]. This equipment was considered in the selection of the worst-case design basis fire (DBF), used in the MPFL calculation (See Sections 5.1 and 6.5.6.1).

The high-value property is:

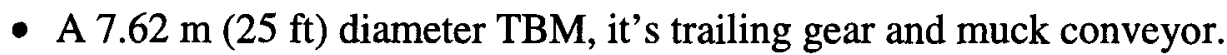

- A $5.5 \mathrm{~m}$ (18 ft) diameter TBM, it's trailing gear and muck conveyor.

- Main drift muck conveyors (if used).

- Rolling stock and mobile equipment.

Dollar value loss estimates will be addressed under future activities.

\subsection{FIRE HAZARDS}

Fire hazards are well understood and documented for the construction activities that will be required during the repository development phase. These fire hazards are discussed in detail in the Subsurface Fire Hazards Analysis (CRWMS M\&O 1998a, Section 7.5) for the ESF (Assumption 5.1) and the Monitored Geologic Repository Internal Hazards Analysis (CRWMS M\&O 2000h). The FHA discussion includes study findings from the U.S. Bureau of Mines that identify the major contributing causes to most underground fires to be poor maintenance, poor housekeeping, and the ready availability of fuel. (Note: Since its disbandment, the safety and health functions of the former U.S. Bureau of Mines are located in the National Institute for Occupational Safety and Health).

The decision to withdraw Controlled Project Assumption 025 (Curry 2001, Table 6-1) that: "diesel-engine-driven equipment will not be used for normal construction and operation of the repository," made since the initial revision 00 of this report, reintroduces diesel fuel as a major potential contributing cause of underground fires. Fire due to short circuits in electrical systems is the other most likely contributing cause of fires. 


\subsubsection{Tunnel Boring Machines, Railcars, and Mobile Equipment}

\subsubsection{Hazards}

TBMs will carry:

- Combustible fluids in onboard reservoirs. See Attachment I; pages I-1 and I-2 for details of fluid type and quantities.

- Dry electrical transformers

- Multiple electrical cables.

Maintenance Railcars will carry:

- Combustible fluids in onboard storage containers. See Attachment I; page I-3 for details of fluid type and quantities.

- Fluid transfer pumps.

Explosives Railcars will carry:

- Explosives and detonators in dedicated storage containers. See Attachment I; page I-4 for details of quantities.

Locomotives:

- Electrically powered locomotives will have electric drive motors and backup battery power system, which will present a small risk for explosion. Other systems present minimal fire hazards. See Attachment I; page I-10 for details of quantities.

- Diesel-powered locomotives will carry diesel fuel. See Attachment I; page I-11 for details of quantities.

- Each type of locomotive will have grease in wheel bearings, etc. See Attachment I; pages I-10 and I-11 for details of quantities.

- Instrumentation and control systems

Other mobile equipment - Road header machines, drill jumbos, load haul dumps, crane cars, and manlifts will have electrical equipment and/or diesel fuel and some other combustible fluids. See Attachment I; pages I-5, I-6, I-7, I-8, and I-9 for details of quantities. 


\subsubsection{Mitigation}

The TBMs' main hydraulic systems and lube-oil system will be protected by pre-engineered multipurpose dry chemical extinguishing systems (See Section 6.8.3.6). Fire-resistant hydraulic fluids will be used in construction equipment.

Fire resistant hydraulic fluids will be Class IIIB (high flash point) combustible liquids. A Class IIIB combustible liquid is defined in Section 1-7.3.1(c) of NFPA 30 as "Any liquid that has a flash point at or above $200^{\circ} \mathrm{F}\left(93^{\circ} \mathrm{C}\right) . "$

Onboard electrical systems will be protected by portable multipurpose dry chemical fire extinguishers (See Section 6.8.3.8). The transformers will be dry (Criterion 4.2.4.1), and wiring insulation will be fire-resistant (Criterion 4.2.4.2). Batteries will be selected to minimize hydrogen offgassing during charging. Electrical cables will be fire-resistant (Criterion 4.2.4.2). The cable fire-resistance criteria have not been established yet.

The maintenance railcar will be protected by pre-engineered multipurpose dry chemical extinguishing systems (See Section 6.8.3.6). The maintenance railcar storage and transfer system will be constructed in accordance with NFPA 385 requirements.

The locomotives will carry portable multipurpose dry chemical fire extinguishers (See Section 6.8.3.8). Batteries will be selected to minimize hydrogen offgassing during charging. Electrical cables will be fire-resistant (Criterion 4.2.4.2). Diesel locomotives will be protected by pre-engineered multipurpose dry chemical extinguishing systems (See Section 6.8.3.6).

Diesel-powered mobile-equipment will be protected by onboard pre-engineered multipurpose dry chemical extinguishing systems (See Section 6.8.3.6).

Backup incipient firefighting capability will be provided to fight mobile-equipment hazards and fixed systems, such as wood ties, if used, by fire hose stations located in the mains and emplacement drifts under construction (See Sections 6.8.3.5 and 6.8.3.9).

\subsubsection{Fixed Electrical Equipment}

\subsubsection{Hazards}

All electrical equipment has the potential to cause a fire. The power distribution systems will include switchgear, rectifiers, transformers, and cables.

\subsubsection{Mitigation}

Electrical power equipment will be designed to meet the appropriate electrical hazard classification in accordance with Occupational Safety and Health Administration (OSHA) [(Criterion 4.2.8.2) 29 CFR 1926, Subpart K] and the National Electrical Code (NFPA 70). Switchgear, rectifiers, motor control centers, and transformers will be enclosed in cabinets. The cabinets will be designed 
to adequately contain a fire, thus isolating these as sources of ignition. Transformers will be dry types (Criterion 4.2.4.1). Over-current and multiple relay protection, and current-limiting fuses will be provided. Cabling will consist of fire-resistant cables (Criterion 4.2.4.2) that are of the self-extinguishing type (See Section 6.5.1.2). Batteries will be selected to minimize hydrogen offgassing as a potential explosion hazard.

Primary incipient firefighting response will be manual, with portable multipurpose dry chemical fire extinguishers (See Section 6.8.3.8) located along the mains, emplacement drifts, and in equipment alcoves. Backup incipient firefighting capability will be provided by fire hose stations located in the mains and emplacement drifts under construction (See Sections 6.8.3.5 and 6.8.3.9).

\subsubsection{Muck Conveyors}

\subsubsection{Hazards}

Fire hazards are well understood and documented for the muck conveyors that may be used during the repository development phase. These fire hazards are discussed in detail in the Subsurface Fire Hazards Analysis (CRWMS M\&O 1998a, Section 7.5.3.1) for the ESF (Assumption 5.1). The muck conveyors, if used in the development phase of the repository, will be designed using similar specifications to those used in the ESF.

\subsubsection{Mitigation}

The conveyor belting will be compounded with fire-retardant additives that meet test criteria that are not yet selected. Since conveyor-fires are generally caused by faulting electrical equipment or friction at drives or pulleys, the conveyor systems will be provided with slippage and alignment switches to stop the conveyors automatically before friction can start a fire. The conveyors will also be interlocked to stop both upstream and downstream transport equipment in case of such problems.

Pre-engineered multipurpose dry chemical extinguishing systems (See Section 6.8.3.6) will be installed at all conveyor head, tail, drive and take-up pulleys. In addition, portable multipurpose dry chemical extinguishers (See Section 6.8.3.8) will be located at all these areas and at intervals along the length of the conveyors.

Backup incipient firefighting capability will be provided by fire hose stations located in the mains and emplacement drifts under construction (See Sections 6.8.3.5 and 6.8.3.9).

\subsubsection{Operations and Monitoring Systems}

Because of the uncertainty as to actual routing of the operations, monitoring and control system fiber networks throughout the repository, these systems are not evaluated for hazards and mitigation in the development area. 


\subsubsection{Other}

\subsubsection{Hazards}

Steel inverts will be used throughout new drift construction (CRWMS M\&O 1998d, Figure 7-3) for the duration of the excavation only. These inverts will be removed during the construction of the infrastructure needed for the emplacement operations. Steel inverts present no fire hazard.

Small amounts of combustibles may be stored underground, though it is not presently intended to have designated storage areas. Materials such as paper, and clean-up rags would be in this category. In addition, combustible trash may accumulate around work areas.

\subsubsection{Mitigation}

None required for the steel inverts.

OSHA [(Criterion 4.2.8.2) 29 CFR 1926.800(m)] and NFPA (NFPA 122) regulations prohibit or limit the storage and/or use of various materials. Synthetics have replaced many of the hydrocarbons used for oils, greases and hydraulic fluids. Good housekeeping will need to be enforced to prevent the accumulation of trash, oily rags and other combustible materials.

Incipient firefighting response will be manual, with portable multipurpose dry chemical fire extinguishers (See Section 6.8.3.8). Backup incipient firefighting capability will be provided by fire hose stations located in the mains and emplacement drifts under construction (See Sections 6.8.3.5 and 6.8.3.9).

\subsubsection{Design Basis Fire}

The DBF is the single worst case fire scenario (Assumption 5.2) for the development fire area with no mitigating actions to suppress the fire. This is postulated to be a fire that destroys, or renders

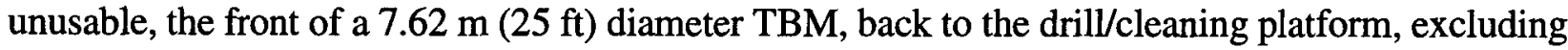
the mapping gantry.

The effects of the DBF are not postulated to affect any important-to-radiological-safety equipment in the emplacement fire area due to the barrier constraints (See Section 6.2.3). The final determination of the fire resistance rating of the barrier required to achieve this level of protection needs to be made. The DBF size and duration need to be quantified to make this determination. Ventilation systems will be distinctly separate (Criterion 4.2.7.2).

The TBM and its muck conveyor has been selected as the most likely source of the DBF because it is the major source of fuel identified in the Subsurface Fire Hazards Analysis (CRWMS M\&O 1998a, Section 7.5.11) for the ESF (Assumption 5.1). The hazards associated with this equipment are discussed in Sections 6.5.1.1 and 6.5.3.1. Other possible fire scenarios are discussed in Section 6.5.7. 


\subsubsection{Design Basis Fire Maximum Possible Fire Loss Estimate}

1994 Estimate (Assumption 5.1):

\$25 million (CRWMS M\&O 1994, Attachment II)

Escalating the $\$ 25$ million to 2001 Dollars will not increase the estimate significantly. The increase is likely to be around 20 percent for an estimate significantly less than $\$ 50$ million (Criterion 4.2.2.3).

\subsubsection{Design Basis Fire Mitigation}

The DBF postulates no threat to important-to-radiological-safety equipment due to the separate ventilation systems and the fire barrier constraints. Since the MPFL exceeds $\$ 1$ million (Criterion 4.2.2.2), mitigation for the DBF will be provided by installing automatic fire-extinguishing systems on the TBMs and their muck conveyors (See Sections 6.5.1.2 and 6.5.3.2). Since the MPFL does not exceed $\$ 50$ million (Criterion 4.2.2.3), redundant fire-extinguishing systems are not mandated.

\subsubsection{Additional Fire Scenarios}

Diesel-powered mobile-equipment may be used (See Section 6.5) in the construction development of the repository. Consequently, most of the additional fire scenarios discussed in the Subsurface Fire Hazards Analysis (CRWMS M\&O 1998a, Section 7.5.12) for the ESF (Assumption 5.1) will occur in the development phase of the repository. Fire scenarios in equipment alcoves are not included here, as location, size, and intended use are not available. One of the applicable scenarios is a maintenance railcar fire in the drift.

\subsubsection{Hazards}

A fire, resulting from an accident with the maintenance railcar, either during transportation in the drift or when transferring the combustible liquid contents of the onboard storage tanks to a TBM, has the potential to propagate rapidly beyond the incipient stage. Large quantities of fuel could be released into the railcar's secondary containment or the bottom of the drift where any subsequent fire would spread quickly, involve adjacent equipment and exceed the operators' ability to contain it.

\subsubsection{Mitigation}

The maintenance railcar scenario poses no threat to important-to-radiological-safety equipment due to the ventilation barrier constraints. Since property loss could exceed $\$ 1$ million (Criterion 4.2.2.2), mitigation will be provided. The maintenance railcar will be protected by onboard pre-engineered multipurpose dry chemical extinguishing systems (See Sections 6.5.1.2 and 6.8.3.6).

A spill fire that exceeds the incipient firefighting manual-response capability of the railcar operators would require that personnel evacuate the tunnel. Evacuation would follow the emergency action plan (See Section 6.14). 


\subsection{LIFE-SAFETY CONSIDERATIONS}

\subsubsection{Occupancy}

The development fire area is classified for occupancy (Criterion 4.2.2.1) as described in Table 3.

Table 3. Development Fire Area Occupancy Classification

\begin{tabular}{|l|l|}
\hline \multicolumn{1}{|c|}{ Subsurface Area } & \multicolumn{1}{|c|}{ NFPA 13 Classification } \\
\hline Development Fire Area & Ordinary, Group 1 \\
\hline
\end{tabular}

The fire hazards in the development fire area are low to moderate and are classified as an "Ordinary Hazard, Group 1" occupancy per NFPA 13 (Criterion 4.2.8.5).

\subsubsection{Ventilation}

The design and planned operation of the repository ventilation system is currently conceptual, however, the ventilation needed for construction is expected to be similar to Option C/Alternate 2 described in Section 6.2.4. The ventilation system will provide fresh air for a maximum of 353 persons (Criterion 4.2.7.1) in the development area during normal operations and is required to provide for smoke removal and containment (Criterion 4.2.3.7). Smoke removal is achieved by either drawing the smoke through the tunnels (as in the global system) or by capturing it through air ducts (as in the local systems) (See Section 6.2.4). In both cases, the goal is to provide a safe path for personnel egress. The DBF size and duration need to be quantified (See Section 6.5.6) and smoke and combustion byproduct flow and concentration evaluated with the ventilation design.

\subsubsection{Egress}

\subsubsection{Navigation in the Repository}

Movement of personnel and materials throughout the repository is a function of the repository construction chronology. In the development phase, entry and egress during construction is only through the access ramps until such time that one of the shaft excavations becomes available. The locations of the ventilation shafts are shown in Figure 1. Both ramp portals are available and act as dual accesses to the construction site. After waste emplacement begins, the repository emplacement side becomes a separate operation from the ongoing construction. The two operations are isolated from each other, physically, by airlocks formed with ventilation isolation doors. The emplacement side of the repository becomes accessible only through the North Portal/North Ramp. The intake shafts have the potential to be used for emergency egress (See Section 6.6.3.2), as they become available. The development side of the repository becomes accessible only from the South Portal/South Ramp. (Its intake shafts also have the potential to be used for emergency egress, as they become available). For certain off-normal conditions, passage through the isolation doors to the emplacement side can be accommodated. 


\subsubsection{Development Phase Construction Egress}

Excavation of the perimeter mains will be completed early in the development phase construction to provide access for further excavation. As excavation of the perimeter drifts proceeds, personnel will be unable to walk out to the surface within the required time limit of one-hour (Criterion 4.2.3.9). Once the maximum egress distance of $4,200 \mathrm{~m}$ (Criterion 4.2.3.10) is reached, emergency refuge stations (ERSs) will be established (See Section 6.6.5).

Following completion of the perimeter drives the exhaust main drift and the first emplacement panel will be constructed. (An emplacement panel consists of a group of constructed emplacement drifts transferred to emplacement operations). Emplacement panels can include standby and/or cross-block drifts.

As development construction progresses, access to ventilation shafts will provide potential additional emergency egress points. The use of shafts for emergency egress requires further evaluation.

\subsubsection{Emplacement Panel Construction Egress}

As noted, egress distances change because emplacement phase construction is not static. As emplacement panel construction progresses, existing ERS locations, relative to the North Portal exit and the shafts, will need to be reviewed for criteria compliance. Additional ERSs may need to be constructed.

\subsubsection{Emplacement, Observation and Post-Closure Test Drifts}

A single means of egress is available to escape from a fire or other emergency in an emplacement, standby, cross-block, observation, or post-closure test drift under construction. The exit path is to travel, as much as $1.0 \mathrm{~km}$ (Figure 1), toward the main drift. Once in the main tunnel, at least two means of egress are available.

There are two possible fire-emergency scenarios in such a drift. These are a fire at the TBM, and a fire in the working drift or main drift behind the TBM.

A fire at the TBM will require personnel to evacuate toward the main drift. A safe pathway will be available to go in that direction since fire gases will be exhausted by the ventilation duct to South Portal atmosphere. External fire protection of the cabling and motors may be required to accomplish this (Criterion 4.2.3.7). Once in the main tunnel, the choice of direction for evacuation of personnel will be determined by the status of the main drift ventilation system and construction activities. The repository emergency action plan will provide the basis for determining evacuation procedures (See Section 6.14).

A fire in the working drift or main drift behind the TBM has potential life-safety threats. Evacuation of personnel at the TBM or between the incident and the main drift may not be feasible depending on the severity of the incident and the smoke/combustion byproducts generated. An ERS or equivalent means of providing life safety is required in the working drift to provide life-safety protection for the personnel. If an ERS is selected as the solution, the type, size, and location of this 
ERS need to be evaluated in the design of ERSs (See Section 6.6.5). The DBF for this scenario also requires to be quantified.

The life-safety risks to personnel operating the TBM, the muck-out railcars, and haulage locomotives, will be minimized by conducting all maintenance at the TBM in the off-shifts, since the maintenance railcar carries significant quantities of combustible fluids (See Section 6.5.1.1). In addition, a cache of self-contained, oxygen-generating, self-rescuers (SCSRs) will be maintained onboard the TBM.

\subsubsection{Personal Respiratory Protection}

All subsurface personnel will be required to be trained in the use of, and to carry personal self-rescuers (SRs). The standard unit carried is suitable for escape from fire where there is sufficient oxygen. These units remove carbon monoxide generated in a fire and are rated for about 60 minutes of moderate to heavy working activity. These units do not include eye protection. Consequently, activity in even moderate amounts of smoke will be extremely difficult.

The worst-case walkout-distance to the surface will greatly exceed the 60-minute capability of a personal SR or SCSR. Significant life-safety improvements can be achieved by providing all subsurface personnel with the SCSRs. These units are National Institute for Safety and Health/Mine Safety and Health Administration rated for 60 minutes of use in moderate to heavy working conditions, as discussed in the Subsurface Fire Hazards Analysis (CRWMS M\&O 1998a, Section 7.6.3) for the ESF (Assumption 5.1). They include eye goggles which would make escape in smoke possible. These SCSRs will give personnel the means to reach an ERS safely within 30 minutes (Criteria 4.2.3.9 and 4.2.3.10), and provide protection against exposure to other harmful gases that may be present besides carbon monoxide or oxygen deficiency. The latest models of these SCSRs weigh about six pounds, as discussed in the Subsurface Fire Hazards Analysis (CRWMS M\&O 1998a, Section 7.6.3) for the ESF (Assumption 5.1). The units are bulky and placing storage caches at emergency assembly points throughout the development phase of the repository may be more practical than requiring personnel to always carry these. Assembly points should be located within easy walking range of the SRs for all subsurface personnel.

\subsubsection{Emergency Refuge Stations}

Emergency refuge stations will be provided (Criteria 4.2.3.9 and 4.2.3.10). Emergency refuge station design and location are yet to be determined.

\subsubsection{Alarm/Notification Systems}

An alarm/notification system will be installed throughout the development phase of the repository (Criteria 4.2.3.5 and 4.2.3.6) in accordance with NFPA 72 (Criterion 4.2.8.6).

\subsubsection{Exit and Emergency Lighting}

Exit and emergency lighting will be installed in the development phase of the repository (Criterion 4.2.8.2) in accordance with OSHA standards. 


\subsection{EXPOSURE FIRE POTENTIAL}

The probability of a fire igniting in the South Ramp, the primary access to the development phase of the repository, due to exposure from an ongoing fire outside the Portal entrance, is postulated as extremely low. Similarly, the probability of a fire igniting in the North Ramp, one of the initial accesses to the development phase of the repository, due to exposure from an ongoing fire outside the Portal entrance, is postulated as extremely low. Surface facilities are of noncombustible construction and are physically removed from the tunnel entrances. OSHA regulations [(Criterion 4.2.8.2) 29 CFR 1926.800(m)(7)] also prohibit the storage of flammable and combustible materials within $30 \mathrm{~m}$ (100 feet) of the portals to reduce the possibility of a fire.

A surface fire, involving a muck conveyor, could cause a burning return belt, or a belt that has burned in two, to transport the fire into the tunnel. Either scenario is postulated as unlikely and would occur only if the belt safeguards, speed switches etc., and fire-retardant capabilities of the belting fail. Fire protection systems, at the drive, would also have to fail for this to occur with an operating conveyor.

The probability of fire propagation will be limited by compliance with procedures written to comply with OSHA [(Criterion 4.2.8.2) 29 CFR 1926] and NFPA 122 controlling the storage of flammable and combustible liquids. The occurrence or spread of fire will be minimized by requirements for containers and safe separation distances from ignition sources and explosives. Also, see Section 6.8.1.

The most likely exposure to a main drift would be from an emplacement drift fire. Exposure from an emplacement drift fire is unlikely to be serious. Emplacement drift ventilation (local ventilation) air will draw the fire energy and fire byproducts away from the main drift, down the emplacement drift and exhaust to the surface through the vent duct.

Exposure to a fire from the Emplacement Fire Area is considered very unlikely. The isolation barriers will be fire-rated (Criterion 4.2.3.3 and Section 6.2.3) and consist of a double airlock. The ventilation systems on each side of the barrier operate totally independently (Criterion 4.2.7.2).

\subsection{FIRE PROTECTION FEATURES}

The objective of the fire protection program is to provide the means to control, prevent propagation, and extinguish subsurface fires (Criterion 4.2.1.1).

\subsubsection{Fire Prevention}

Fire prevention practices fall into three categories: limiting fuel sources; limiting ignition sources; and limiting ignition source contact. 


\subsubsection{Limiting Fuel Sources}

Limiting fuel sources is discussed in detail in the Subsurface Fire Hazards Analysis (CRWMS M\&O 1998a, Section 7.8.1.1) for the ESF (Assumption 5.1). The majority of the hazards identified for the ESF will be similar in the development phase of the repository. Specific quantities of fluids used in the construction equipment may be expected to change, but the same basic discussion applies. Use of low (or reduced) hazard material will be required. Fire-resistant conveyor belting, hydraulic fluids, hydraulic hoses, electric cable insulation, and ventilation ducting will be used to the maximum extent possible.

Storage of combustible liquids underground will be kept to a minimum and only done in compliance with OSHA [(Criterion 4.2.8.2) 29 CFR 1926.800(m)] and NFPA 122 requirements. Sealed bearings will be used, primarily for environmental containment, thus reducing exposure of greases.

Maintenance railcars that transport hydraulic fluid, lubricating oil, and grease to refurbish the TBMs will be constructed and operated in accordance with NFPA 385 requirements.

Transient combustibles and materials will be limited and controlled by administrative procedure.

\subsubsection{Limiting Ignition Sources}

High and medium voltage power-distribution equipment will be installed in appropriately designed cabinets, thus isolating this source of ignition. Transformers will be dry types (Criterion 4.2.4.1), also in cabinets. In case of an electrical fire inside a cabinet, the risk of fire propagation to adjoining equipment is considered extremely low. Circuits will have fuse, thermal cutout, multiple relay, and over-current protection built-in.

Smoking will be strictly controlled to minimize matches and lighters as sources of ignition.

\subsubsection{Limiting Fuel and Ignition Source Contact}

The primary hazard will occur during maintenance operations. Precautions will be observed during welding and cutting operations, and will follow NFPA 51B and OSHA (Criterion 4.2.8.2) requirements. Nearby combustibles will be covered with fire-resistant materials or moved. Fire extinguishers will be readily available and a trained fire-watch posted for as long as necessary to guard against smoldering fires.

Smoking will be restricted to areas free of fire hazards, in accordance with OSHA regulations [(Criterion 4.2.8.2) 29 CFR 1926.800(m)(2)(i)].

\subsubsection{Explosion Prevention}

Explosion prevention practices fall into the same three categories as those for fire prevention: limiting fuel sources; limiting ignition sources; and limiting ignition source contact. 
Methane gas and dust are the primary fuels involved in underground mine explosions. The ESF has been classified as non-gassy (CRWMS M\&O 1993, Section 11) and the rock is inert. Therefore, the potential for such an explosion in the repository is considered extremely unlikely. The underground ventilation system will be monitored and will provide warning of underground environmental conditions dangerous to personnel.

Welding gases brought in for maintenance purposes will be strictly inventoried and will follow the requirements of NFPA 51B.

Explosives will be transported underground in either a dedicated container on a railcar, or a dedicated railcar, each built in accordance with Mine Safety and Health Administration regulations (30 CFR 57, Subpart E, 57.6201; 57.6202; 57.6203; 57.6205). Explosives will only be transported into the development areas when required for specific tasks, such as alcoves and ERSs. The use of explosives will be kept to a minimum.

Battery explosion prevention on back-up power systems in mobile equipment will primarily rely on proper battery selection. Batteries will be selected to minimize hydrogen offgassing. If locomotives use continuous onboard battery charging, current-limiting devices will be required. It is preferable that charging be done on the surface in well-ventilated areas.

\subsubsection{Fire Protection}

Fire protection is provided by the use of onboard automatic fire-extinguishing systems, automatic fire detection and alarm systems, and backup by manual fire hose systems (Criteria 4.2.3.1 and 4.2.3.2). If an onboard system fails, the backup water system is available for protection. Since this is a construction area, the response to a fire emergency should be rapid, allowing manual firefighting while still in the incipient stage.

\subsubsection{Choice of Extinguishing Agents}

The rationale for the choice of extinguishing agents is discussed in detail in the Subsurface Fire Hazards Analysis (CRWMS M\&O 1998a, Sections 7.8.2.1, 7.8.2.2, 7.8.2.3, 7.8.2.4, and 7.8.2.5) for the ESF (Assumption 5.1) and the conclusions are summarized in the following sections.

\subsubsection{Dry Chemical Agents}

Multipurpose dry chemical agents are discussed in detail in the Subsurface Fire Hazards Analysis (CRWMS M\&O 1998a, Section 7.8.2.2) for the ESF (Assumption 5.1). The specific agent selected for use in the ESF and now for the development phase of repository construction is monoammonium phosphate.

\subsubsection{Clean-Agents}

Clean-agents are discussed in detail in the Subsurface Fire Hazards Analysis (CRWMS M\&O 1998a, Section 7.8.2.3) for the ESF (Assumption 5.1). "Clean Agent" is the 
generic term used by NFPA to describe "halon replacement" extinguishing agents (NFPA 2001, Section 1-2.1). Two agents are being used in the ESF. These are "FM-200 and FE-36."

\subsubsection{Water}

Water usage is discussed in detail in the Subsurface Fire Hazards Analysis (CRWMS M\&O 1998a, Section 7.8.2.4) for the ESF (Assumption 5.1). This is a recommended extinguishing agent.

\subsubsection{Recommended Extinguishing Agents}

The recommended repository extinguishing-agents for primary fire protection are discussed in detail in the Subsurface Fire Hazards Analysis (CRWMS M\&O 1998a, Section 7.8.2.5) for the ESF (Assumption 5.1). The recommended repository extinguishing-agent for primary fire protection is multipurpose dry chemical.

Clean-agent portable fire extinguishers are recommended specifically for use in locations frequented by personnel with limited extinguisher training. These present minimal hazard to these personnel and do not obscure vision when the agent is released. Installation of portable fire extinguishers will comply with the requirements of NFPA 10 (Criterion 4.2.8.9).

In recognition of some of the limitations of dry chemicals and clean-agent, firewater is recommended and will be provided, by distribution main, along the length of the main drift and emplacement drift excavations. Fire hose stations will be provided along the firewater main. The main installation will comply with NFPA 24 (Criterion 4.2.8.7). See Section 6.8.3.9 for hose installation.

\subsubsection{Pre-engineered Extinguishịing Systems}

Automatic pre-engineered dry chemical extinguishing systems will be installed on the TBMs, muck conveyors, any diesel-powered mobile-equipment and maintenance rail-cars and will use monoammonium phosphate, a multipurpose dry chemical powder, as the fire-extinguishing agent. The systems will be UL and/or FM listed and be installed in compliance with OSHA [(Criterion 4.2.8.2) 29 CFR 1926, 800(k)(10)(ii)] and NFPA 17 requirements. These systems will be activated automatically by onboard fire detection systems that will be integrated with the extinguishing systems and other tunnel fire alarm systems (Criterion 4.2.3.5).

\subsubsection{Detection and Alarm Systems}

Dedicated automatic and manual fire detection and alarm systems will be installed throughout the development phase of the repository (Criteria 4.2.3.5; 4.2.3.6). The detection and alarm systems will be installed in compliance with NFPA 72 (Criterion 4.2.8.6). 


\subsubsection{Portable Extinguishers}

Incipient firefighting response will be manual, with portable multipurpose dry chemical and clean-agent extinguishers. Portable fire extinguishers will be installed in compliance with NFPA 10 (Criterion 4.2.8.9). Extinguisher spacing will be determined as the system design proceeds.

\subsubsection{Hose Systems}

To provide backup incipient firefighting capability, fire hose stations will be installed throughout the repository main drifts and emplacement drifts. The provision of a backup system conforms to the general NRC guidance (NRC 1981, Section C.1.c.1) which states that: "Total reliance should not be placed on a single fire suppression system. Appropriate backup fire suppression capability should be provided." Each installation will include a storage rack, and fire hose, with UL listed (Criterion 4.2.3.8), electrically-safe shut-off type nozzle. Hose stations will comply with NFPA 14 (Criterion 4.2.8.8). Hose station spacing will be determined as the system design proceeds.

\subsection{POTENTIAL FOR A HAZARDOUS INCIDENT}

The potential for a toxic, biological and/or radiation incident due to a fire is not considered significant:

- Most materials selected for construction are essentially inert.

- Burning electrical cables can emit potentially toxic gases as products of combustion. The risk of combustion occurring is low, due to the expected use of fire resistant cables and by separating the power cables from any non fire-rated instrument cables. The effects of potentially toxic gases are also partially mitigated by dilution in the ventilation system airflow.

- Biological and radioactive materials are not present during construction of the development phase of the subsurface repository.

- Normal or accidental release of a fire protection water system may result in the accumulation or ponding of water in the subsurface facility. The water collection/removal system is a CQ system (Table 1) and will need to be designed to prevent hydrological damage to the natural barrier. The only proposed use of water for fire protection is for fire hose stations.

\subsection{NATURAL HAZARDS}

The MGR External Events Hazards Analysis Hazards List (CRWMS M\&O 2000e, Section 7.1) identifies potential candidates for the 100-year operational period MGR DBEs. 


\subsubsection{Potential Hazards Impacting Fire Safety}

The following identified potential natural hazards may have limited impact on fire safety and will be considered in the design of fire protection systems.

\subsubsection{Hazards}

- Flooding (storm, river diversion) (CRWMS M\&O 2000e, Section 7.1)

- Lightning (CRWMS M\&O 2000e, Section 7.1)

- Seismic Activity, Earthquake (CRWMS M\&O 2000e, Section 7.1)

- Seismic Activity, Subsurface Fault Displacement (CRWMS M\&O 2000e, Section 7.1)

\subsubsection{Mitigation}

Floodwater intrusion is not expected since the portals are above the probable maximum flood level (BSC 2001, Section 6.1.2.5).

Lightning protection will be provided by designing systems to comply with NFPA 780 (Criterion 4.2.4.4).

Fire protection systems will be designed to withstand seismic activity. Design criteria for these systems have not yet been selected.

\subsubsection{Potential Hazards with No Impact on Fire Safety}

The following identified potential natural hazards have no impact on fire safety.

\subsubsection{Hazards}

- Debris Avalanching (CRWMS M\&O 2000e, Section 7.1)

- Extreme Wind (CRWMS M\&O 2000e, Section 7.1)

- Landslide (CRWMS M\&O 2000e, Section 7.1)

- Tornado (CRWMS M\&O 2000e, Section 7.1)

\subsubsection{Mitigation}

None required.

\subsection{DAMAGE POTENTIAL}

In compliance with nuclear safety requirements (Criterion 4.2.3.3), DOE Orders [(Criterion 4.2.8.3) DOE Order 420.1, Section 4.2.2.3], and Criteria 4.2.2.2 and 4.2.2.3, the following requirements have been evaluated: 
An automatic fire-extinguishing system is required whenever the facility is subject to the following:

- Where important-to-radiological-safety equipment are vulnerable to credible fire and explosion hazards

- Unacceptable program interruption

- Fire loss potential greater than $\$ 1$ million

- A redundant fire protection system is also required, whenever the MPFL exceeds $\$ 50$ million, to limit the loss to $\$ 50$ million, despite failure of the primary fire protection system.

\subsubsection{Unacceptable Program Interruptions}

A credible fire could result in the loss of use of part of the facility. This would assume that cleanup is possible without affecting the site beyond acceptable limits. A credible loss could be the loss of portions of either a TBM or a muck conveyor, and some of their power delivery systems as described in Section 6.5.6. A postulated loss for such a scenario is several million dollars. Mitigation will be provided by the installation of pre-engineered automatic fire-extinguishing systems (See Section 6.8.3.6). There should be no significant program interruption potential from a fire originating in a source other than the equipment specifically identified.

\subsubsection{Fire Loss Potential}

The maximum damage potential of a fire in the development phase of the subsurface repository is postulated in the MPFL to be less than $\$ 50$ million (Criterion 4.2.2.3), when one considers the DBF described in Section 6.5.6.

Actuation of a fire protection system, because of a fire, could result in the accumulation or ponding of water in the subsurface facility. The damage potential for associated changes to the hydrological characteristics of the natural barrier is yet to be determined. However, since the proposed water based fire-extinguishing systems are manual (hose systems), the quantities of water used are likely to be low.

The Subsurface Facilities Broad Based Risk Analysis Report (CRWMS M\&O 1999y, Table III-1, Event 38 ) also identifies a fire underground as a potential unplanned construction event.

The analysis assessed this scenario as high risk to personnel safety.

Mitigation of event 38 will be provided by:

- Batteries, if used, selected to minimize hydrogen offgassing (Section 6.5.1.2).

- Using fire resistant cable insulation (Section 6.8.1.1). 
- Minimizing the use and availability of combustible fuels in the development areas (Section 6.5).

- Installation of pre-engineered automatic fire-extinguishing systems on TBMs and mobile equipment (Section 6.8.3.6).

The maximum damage potential of a fire in the development fire area is discussed in Section 6.5.6.1.

\subsection{IMPORTANT TO SAFETY EQUIPMENT}

No systems important-to-radiological-safety or important-to-waste-isolation are identified in the development phase.

\subsection{CRITICAL PROCESS EQUIPMENT}

This criterion does not apply to the development phase of the subsurface repository.

\subsection{EMERGENCY PLANNING}

The operating contractor has the responsibility for developing and maintaining the emergency action plan in accordance with OSHA [(Criterion 4.2.8.1) 29 CFR 1910.38] the Emergency Management Plan (DOE 2000b), and the Emergency Management Procedure (LP-ESH-010-M\&O).

Successful implementation of the emergency plan requires that a central operations control point be provided to handle fire emergencies. The control point would address underground operations, communications and fire status.

\subsection{FIRE DEPARTMENT/BRIGADE RESPONSE}

Firefighting and rescue responsibilities during construction of the repository have not been established yet. In accordance with the current Occupational Safety and Health Program (AP-ESH-004, Section 5.13.4.1, NOTE), it is Yucca Mountain Site Characterization Office (YMSCO) policy that: "All fire fighting shall conform to OSHA requirements and only properly trained and equipped personnel shall fight fires beyond the incipient stage. Beyond incipient stage fires, personnel are expected to disengage and evacuate the facility. Site Access Training and General Underground Training address incipient fire fighting." Therefore, manual firefighting can not be credited to mitigate MPFL determinations. See Section 6.5 for the discussion of automatic fire protection systems that will be installed either to comply with DOE Order valuation requirements (Criterion 4.2.2.2) or to offset the restriction on manual firefighting beyond the incipient stage.

\subsection{RECOVERY POTENTIAL}

The ability to recover from a credible subsurface fire is considered reasonably acceptable. Physical damage to the facility and its contents will be limited by the proposed fire protection systems and the use of fire-resistant or noncombustible material for construction and operation. 
Unacceptable levels of environmental damage, caused by a credible fire, are postulated only if the fire protection systems fail to perform as designed.

\subsection{SECURITY AND SAFEGUARDS}

The development phase of the subsurface repository is an unclassified facility, so there are no security requirements related to fire protection. The only security consideration is related to life safety. Access to the underground facility will be controlled and will be available only to personnel who have completed mandatory training in subjects, such as hazards awareness, use of mine lamps, and use of SRs. 
INTENTIONALLY LEFT BLANK 


\section{EMPLACEMENT FIRE AREA HAZARDS}

\subsection{INTRODUCTION}

The hazards identified for the emplacement phase and their proposed mitigation must be considered as preliminary and scoping in nature. The documents reviewed and referenced were prepared for the Lower-Temperature Operating Mode Site Recommendation design. Due to the unconfirmed status of this information, this report cannot be used as input into documents supporting procurement, fabrication, or construction.

\subsection{CONSTRUCTION}

\subsubsection{Design Elements}

The general configuration of the repository is described in Section 6.2 for both development and emplacement areas. Construction in the Emplacement Fire Area in preparation for emplacement operations will include the installation of the entire infrastructure needed to operate and maintain the repository. This includes the installation of isolation doors, inverts, railroad track, utilities, and instrumentation, etc.

\subsubsection{Fire Boundaries}

During waste emplacement, the Emplacement Fire Area is one of the two defined fire areas (Section 6.2.3). The Emplacement Fire Area hazards are described here in Section 7 of this report. After the development phase is complete, the two fire areas become one large Emplacement Fire Area. When waste emplacement operations are finished and the prescribed repository-cooling period is over the whole repository is expected to be sealed.

\subsubsection{Ventilation System Concept}

The emplacement ventilation concept is described in the Lower-Temperature Subsurface Layout and Ventilation Concepts analysis (BSC 2001, Section 6.2.3).

During waste emplacement, the ventilation system provides WP cooling and an acceptable environment for equipment operation. After emplacement, the ventilation airflow continues to remove the heat released by the WPs. The ventilation system operates in exhaust mode (fans are located on the surface at each exhaust shaft) during and after the emplacement of waste. The emplacement period is followed by a forced ventilation period of 50 years, which is followed by natural ventilation (i.e., no fans) for 250 years.

Fresh air enters through the intake shafts (See Figure 1), or the North Ramp, and is distributed to the East and/or West mains by shaft access drifts. From the mains, air enters the emplacement, standby, cross-block, and observation/post-closure test drifts and flows into the centrally located exhaust raises. The central exhaust main collects the flow from the raises where it is exhausted to the surface by the exhaust fans through the exhaust shafts. 
Two parallel fans located on each exhaust shaft provide the subsurface repository ventilation airflow needs. The fans are variable flow, so that the air volume can be adjusted to accommodate the repository's thermal cooling requirements as they change with time. Air distribution throughout the repository is controlled by regulators (dampers) located at the intake to each emplacement drift and in the exhaust raises. The fans create a negative pressure at the exhaust main level that is higher than the negative air pressure at the emplacement level, thus ensuring that there is no recirculation from inside the emplacement drifts to the access mains.

\subsection{OPERATIONS}

Emplacement operations will transport the loaded and sealed WP/pallet from the Waste Handling Building (WHB) to the subsurface emplacement area. Transportation starts on the surface at the WHB through the North Portal and proceeds underground via the North Ramp, and access mains to its designated emplacement drift.

The operation starts at the WHB, by placing the WP/pallet onto the extended bedplate of the WP transporter transfer deck where it is then moved inside the WP transporter shield by a remotely controlled mechanism. Two electrically powered transport locomotives are used to move the WP transporter from the WHB into the repository by travelling down the North Ramp, into the East or West Main, and to the vicinity of the designated emplacement drift. At the emplacement drift location, one locomotive is uncoupled from the WP transporter in order to allow the WP transporter, with the shielding doors facing the drift entrance, to be pushed into the emplacement drift turnout. Before the WP transporter is pushed into the turnout, the locomotive operators leave the locomotive and the remainder of the emplacement operations are performed remotely.

Once the WP transporter is partway into the turnout, the WP transporter doors and the drift isolation doors are opened remotely. The WP transporter is then pushed between the rails of the emplacement drift transfer dock. Once the WP transporter is docked, the unloading mechanism moves the WP/pallet/bedplate out of the WP transporter shield onto the transfer deck. The emplacement gantry moves into position over the WP/pallet and lifts it off the bedplate. The WP transporter retracts the bedplate. The gantry carries the WP/pallet into the emplacement drift and lowers it at its predetermined emplacement position. The gantry disengages from the WP/pallet and moves back to its waiting position at the transfer dock.

The WP transporter is disengaged from the emplacement drift transfer dock and then pulled away from the drift entrance doors by the single locomotive. The WP transporter doors and the drift doors are then closed, the operators rejoin the locomotives, the second locomotive is reattached to the WP transporter, and it returns to the surface WHB for another transport and emplacement operation.

The major equipment required for waste emplacement consists of:

- A shielded WP transporter with integrated transfer deck for the movement and transfer of the WPs. The WP transporter requires two transport locomotives for movement. 
- Transport locomotives for WP transporter movement and control functions between the WHB and the subsurface repository.

- A remotely controlled emplacement gantry for WP emplacement in the emplacement drifts. The gantry is self-powered through a third-rail system.

- A gantry carrier to transfer the gantry between the emplacement drifts and/or to the maintenance facilities. The gantry carrier requires a transport locomotive for the carrier movement and control functions.

\subsection{HIGH-VALUE PROPERTY}

The high-value property in the emplacement phase of the repository is:

- Inspection Gantry

- Emplacement Gantry

- Gantry Carrier

- Transport Locomotives

- WP Transporter with integrated transfer deck

- Waste Recovery/Restoration System Equipment

Dollar values will be addressed under future activities.

\subsection{FIRE HAZARDS}

As pointed out in Section 6.5, the major contributing causes to most underground fires are poor maintenance, poor housekeeping, and the ready availability of fuel. In the emplacement area, fuel will not normally be readily available. The permanent construction components in the access ramp, access mains, emplacement and ventilation drifts, and observation and post-closure test drifts will be non-combustible. The electrically powered mobile-equipment used to transport, emplace, inspect, and recover the WPs will be constructed of non-combustible materials. Equipment maintenance will be performed on the surface, subsurface maintenance will be strictly controlled, and materials will be inventoried to minimize the risks of brought-in combustible materials.

Abnormal operations, such as may be necessary for waste recovery, will likely use some diesel-powered specialty equipment.

Fires due to short-circuits in electrical systems are the most likely remaining contributing cause of fires in the emplacement phase of the repository. The fixed electrical distribution system will be designed to meet the nationally recognized electrical codes and standards (Criterion 4.2.4.3). Installation to these standards will minimize, but not totally remove, the probabilities of an electrical short-circuit starting a sustainable fire. 


\subsubsection{Waste Emplacement/Retrieval \& Recovery Equipment (Normal Conditions)}

\section{Term definition:}

- "Retrieval" is used to indicate removal of groups of WPs or the entire inventory of WPs from the underground.

- "Recovery" is used to indicate selective removal of a small set of WPs from the underground.

- "Normal Conditions" refers to a subsurface environment that is performing essentially as expected (e.g., retrieval or recovery after forced ventilation of an emplacement drift).

\subsubsection{Hazards}

The Emplacement Gantry (CRWMS M\&O 2000f, Section 6.1) is classified QL-3 (Table 2) and the Inspection Gantry is classified QL-3 (Table 2) and each will have:

- Multiple electrically powered drive motors

- Air conditioned electrical enclosures

- Control and communications systems.

All these systems present minimal fire hazards. See Attachment II; pages II-1 and II-2, for data sheets.

The Gantry Carrier (CRWMS M\&O 1998c, Section 7.2) is classified CQ (Table 2) and will have:

- Third-rail power system. Power will be supplied from either the locomotive or the emplacement drift transfer dock.

- Instrumentation and controls systems.

These systems present minimal fire hazards. See Attachment II; page II-3, for data sheet.

The WP Transporter (with Transfer Deck) (CRWMS M\&O 2000g, Section 6.4) is classified QL-1 (Table 2) and will have:

- Electrically powered door operators

- Electrically powered rigid chain drive

- Connections to the locomotive for power, controls, air brakes, and redundant brake system

- Instrumentation and controls systems.

All these systems present minimal fire hazards. See Attachment II; page II-5, for data sheet. 
Transport Locomotives (CRWMS M\&O 1998c, Section 7.3) are classified QL-1 (Table 2) and will have:

- Electrically powered drive motors

- Instrumentation and control systems

These systems present minimal fire hazards. See Attachment II; page II-4, for data sheet.

\subsubsection{Mitigation}

Since the gantries will be operated remotely, and radiation and thermal conditions preclude manual fire fighting, their electrical enclosures will be protected by redundant automatic fire-extinguishing systems. These discharge inside the electrical enclosures to immediately extinguish fires caused by electrical shorts and arcing.

No significant fire hazards are identified for the gantry carrier so automatic fire-extinguishing equipment is not required.

The WP transporters will be operated remotely, and are QL-1. Their electrical/control enclosures will be protected by redundant (Criteria 4.2.3.1 and 4.2.3.4) automatic fire-extinguishing systems. The systems will discharge inside the electrical/control enclosures to immediately extinguish fires caused by electrical shorts and arcing.

The transport locomotives are QL-1 and their electrical/control enclosures will be protected by redundant (Criteria 4.2.3.1 and 4.2.3.4) automatic fire-extinguishing systems. The systems will discharge inside the electrical enclosures to immediately extinguish fires caused by electrical shorts and arcing.

The redundant systems provide the backup required by Criterion 4.2.3.1 and assure that inadvertent failure of a fire protection system will not disable the waste emplacement/retrieval and recovery equipment (Criterion 4.2.3.4).

Normal waste retrieval and recovery operations use the emplacement equipment.

\subsubsection{Waste Recovery \& Restoration Equipment (Abnormal Conditions)}

\section{Term definition:}

- "Abnormal Conditions" refers to a subsurface environment that has been disturbed (e.g., a waste emplacement/retrieval system accident, design basis event occurrence).

\subsubsection{Hazards}

The following recovery/restoration equipment are assigned QL-1, QL-2 or QL-3 classifications (Table 2): 
- Bottom Lift Transporter (QL-3)

- Covered Shuttlecars (QL-2)

- Decontamination Equipment (QL-2)

- Emplacement Drift Forklift (QL-3)

- Extendable Conveyor (QL-3)

- Load-Haul-Dump Loader (QL-3)

- Main Drift Forklift (QL-3)

- Modified Waste Package Transporter (QL-1)

- Multi-Purpose Hauler (QL-2)

- Multi-Purpose Vehicle (QL-3)

- Scaling Machine (QL-3)

- Emplacement Drift Gantry Carrier (QL-3)

- Restoration Locomotive (QL-3).

This equipment will be one or both of the following:

- Electrically powered equipment is expected to be used for the majority of the abnormal recovery processes

- Diesel-powered equipment may also be used for some abnormal recovery processes.

Electrically powered equipment will present minimal fire hazards. Diesel-powered equipment will present fire hazards due to hot internal combustion engines and onboard diesel fuel storage tanks. See Attachment II; page II-6, for a typical data sheet for diesel-powered recovery equipment. Individual data sheets will be added, as more design information becomes available.

\subsubsection{Mitigation}

Waste recovery during abnormal operations will require some specialty equipment. Electrically powered specialty equipment (some of which are listed in Section 7.5.2.1) will be analyzed individually, when more information becomes available, for the need for onboard automatic fire-extinguishing systems.

Diesel-powered specialty equipment, if used, will be protected by redundant automatic fire-extinguishing systems (Criteria 4.2.3.1 and 4.2.3.4). The systems will operate automatically, and have the ability to be triggered manually.

\subsubsection{Disposal Containers}

\subsubsection{Hazards}

All of following disposal containers are assigned a "QL-1" classification (Table 2):

- Canistered SNF Disposal Container

- Defense High Level Waste Disposal Container 
- DOE SNF Disposal Container

- Non-Fuel Components Disposal Container

- Uncanistered SNF Disposal Container

- Naval SNF Disposal Container

These containers are non-combustible and present no fire hazard.

\subsubsection{Mitigation}

None required.

\subsubsection{Fixed Electrical Equipment}

\subsubsection{Hazards}

The electrical distribution systems are CQ (Table 2) and will include switchgear, rectifiers, transformers and cables. These all have the potential to cause a fire.

\subsubsection{Mitigation}

The switchgear, rectifier units and transformers will be located in their own alcoves. This would put the equipment outside the transportation corridor, preventing physical damage in the unlikely event of a transporter derailment. The switchgear and transformers will be installed in cabinets isolating these as sources of ignition. Electrical cables will be fire-resistant (Criterion 4.2.4.2). The cable fire-resistance criteria have not been established yet.

\subsubsection{Operations, Monitoring, and Control Systems}

\subsubsection{Hazards}

The OMCS is classified QL-2 (Table 2) and contains some components that could affect the project's ability to assure the public's safety and health if damaged by a fire.

\subsubsection{Mitigation}

The preliminary OMCS design uses a dual-ring network (two cables, two fibers per cable) to connect to subsurface processes regarded as critical to safety (Criterion 4.2.6.1) with doubly redundant (four circuits) links to all LANs. If a fire damages the network to a monitoring/control supervisory station, the redundant network will be used to maintain necessary monitoring and control functions. Thus, a fire will not cause loss of function of a QL-1 system. However, depending on the actual routing of these systems, additional fire protection may be required for the network systems. 


\subsubsection{Infrastructure}

\subsubsection{Hazards}

The following infrastructures are assigned QL-1 or QL-2 classifications (Table 2):

Emplacement Drift System:

- Invert (QL-2)

- WP Emplacement Pallet (QL-2)

- Drip Shield (QL-1)

Ground Control:

- Emplacement Drifts (QL-2)

Subsurface Facility System:

- Emplacement Drifts (QL-1)

All of these infrastructures are non-combustible and present no fire hazard.

\subsubsection{Mitigation}

None required.

\subsubsection{Other}

\subsubsection{Hazards}

Other hazards include maintenance activities using welding gases and the accumulation of trash, oily rags and other combustible materials.

\subsubsection{Mitigation}

Administrative controls will comply with NFPA 801 (Criterion 4.2.8.10).

\subsubsection{Design Basis Fire}

The DBF for the emplacement fire area will be determined after more design information becomes available. However, a mitigated DBF, concurrent with a single failure of a fire protection system, should not exceed the bounding WP design basis external fire event [10 CFR 71, Section 73(c)(4)]. The bounding WP Design Basis Event for thermal and structural design is defined as: "Exposure of whole WP for not less than 30 minutes to a heat flux not less than that of a radiation environment of $800^{\circ} \mathrm{C}$ with an emissivity coefficient of at least $0.9 . "$ 


\subsubsection{Design Basis Fire Maximum Possible Fire Loss Estimate}

A dollar value loss estimate will be assigned under future activities.

\subsubsection{Design Basis Fire Mitigation}

The adverse effects of fire-extinguishing system agents on nuclear safety and appropriate DBF mitigation need further evaluation.

\subsection{LIFE-SAFETY CONSIDERATIONS}

\subsubsection{Occupancy}

The emplacement fire area is classified for occupancy (Criterion 4.2.2.1) as described in Table 4.

Table 4. Emplacement Fire Area Occupancy Classification

\begin{tabular}{|l|l|}
\hline \multicolumn{1}{|c|}{ Subsurface Area } & \multicolumn{1}{|c|}{ NFPA 13 Classification } \\
\hline Emplacement Fire Area & Ordinary, Group 1 \\
\hline
\end{tabular}

The fire hazards in the emplacement fire area are low to moderate and are classified as an "Ordinary Hazard, Group 1" occupancy per NFPA 13 (Criterion 4.2.8.5).

\subsubsection{Ventilation}

The design and planned operation of the repository ventilation system is currently conceptual, however, the ventilation needed for emplacement is expected to be as described in Section 7.2.3. The ventilation system will provide fresh air for a maximum of 89 persons (Criterion 4.2.7.1) in the emplacement area during normal operations and is required to provide for smoke removal and containment (Criterion 4.2.3.7). Smoke removal is achieved by drawing the smoke through the tunnels by the exhaust fans. The goal is to provide a safe path for personnel egress. The DBF size and duration need to be quantified (See Section 7.5.8) and smoke and combustion byproduct flow and concentration evaluated with the ventilation design.

\subsubsection{Egress}

Several exit points from a fire hazard or other emergency will be available to personnel working in the emplacement phase of the repository. These will include:

- The North Portal

- The ventilation intake shafts (if deemed suitable and necessary) (See Section 6.6.3.3)

- The east access main barrier to the South Portal

- The west access main barrier to the South Portal. 
Egress routes will change over time with each expansion of the emplacement area. The emergency action plan (Section 7.14) will be dynamic in nature and will require frequent revisions to stay current with the construction and operations activities.

\subsubsection{Personal Respiratory Protection}

All personnel will be required to be trained in the use of, and to carry personal SRs. See Section 6.6.4 for a discussion of the type recommended for use.

\subsubsection{Emergency Refuge Stations}

Emergency refuge stations will be constructed and equipped during development of the repository (See Section 6.6.5). As the barriers between emplacement and development areas advance toward the development area, operation and maintenance of the ERSs will pass to emplacement operations. Further evaluation of ERS design is required to assess the impact of the repository thermal and nuclear effects.

\subsubsection{Alarm/Notification System}

The emplacement operations alarm/notification system will be installed throughout the emplacement phase of the repository (Criteria 4.2.3.5 and 4.2.3.6) in accordance with NFPA 72 (Criterion 4.2.8.6).

\subsubsection{Exit and Emergency Lighting}

The emplacement operations exit and emergency lighting will be installed in the emplacement phase of the repository (Criterion 4.2.8.1) in accordance with OSHA standards.

\subsection{EXPOSURE FIRE POTENTIAL}

The probability of a fire igniting in the North Ramp, the primary access to the emplacement phase of the repository, due to exposure from an ongoing fire outside the Portal entrance is extremely low. Surface facilities are of noncombustible construction and are physically removed from the tunnel entrances. OSHA regulations [(Criterion 4.2.8.2) 29 CFR $1926.800(\mathrm{~m})(7)]$ also prohibit the storage of flammable and combustible materials close to the portals to reduce the possibility of a fire.

The probability of fire exposure from the development fire area encroaching into the emplacement fire area is extremely remote. The isolation airlocks will be fire-rated (See Section 6.2.3) and the ventilation systems operate totally independently (Criterion 4.2.7.2).

Since a muck conveyor is not located in the North Ramp, this potential hazard need not be considered. 


\subsection{FIRE PROTECTION FEATURES}

\subsubsection{Fire Prevention}

Fire prevention practices are discussed in Section 6.8.1 for the development phase of the repository. With the exception of references made to TBM operations, the discussion applies to the emplacement phase of the repository. More stringent materials control and general cleanliness will be required in the emplacement operations.

\subsubsection{Explosion Prevention}

Explosion prevention practices will be similar to those for the development phase of the repository (see Section 6.8.2). With the exception of references made to explosives used in construction operations, the discussion applies to the emplacement phase of the repository.

\subsubsection{Fire Protection}

The choices of extinguishing agents and recommendations for extinguishing agents use need further evaluation for their adverse impact on nuclear safety.

The need for manual fire-emergency response and the types of equipment that would be required will be evaluated at some future date (See Section 7.15).

Manual and automatic fire detection (Criterion 4.2.3.3) and fire alarm (Criterion 4.2.3.2) systems will be installed in accordance with Criterion 4.2.3.7 and NFPA 72 (Criterion 4.2.8.6).

\subsection{POTENTIAL FOR A HAZARDOUS INCIDENT}

The potential for a toxic, biological and/or radiation incident due to a fire is not significant:

- Most material selected for construction is essentially inert.

- Burning electrical cables can emit potentially toxic gases as products of combustion. The risk of combustion occurring is low, due to the expected use of special high temperature and fire-rated cables and by separating the power cables from any non fire-rated instrument cables.

- Biological materials are not present.

- Radioactive materials, although present, are contained in the sealed WPs.

- Failure of an emplacement water-based fire-extinguishing system, because of a design basis event, may result in the accumulation or ponding of water in the subsurface facility and the associated changes to the hydrological characteristics of the natural barrier. The decision to use water as a fire-extinguishing agent has not yet been made. 


\subsection{NATURAL HAZARDS}

The impact on fire safety from potential natural hazards will be considered in the design of the fire protection systems. The discussion of natural hazards in Section 6.10 is applicable here.

Fire protection systems will be designed to withstand seismic activity. Design criteria for these systems have not yet been selected.

\subsection{DAMAGE POTENTIAL}

Any fire or explosion in the emplacement areas has the potential to result in the loss of use of the facility. The Monitored Geologic Repository Internal Hazards Analysis (CRWMS M\&O 2000h, Section 7.4.7) determined that a fire hazard might exist for fires associated with the WP transporter/locomotive equipment.

The Subsurface Facilities Broad Based Risk Analysis Report (CRWMS M\&O 1999y, Table III-2, Events 31,54 , and 70 ) also identifies a battery fire/explosion underground as a potential unplanned emplacement event. The three scenarios described are:

- Event 31 - transporting WP from the WHB to emplacement drift

- Event 54 - transporting WP to loading dock and emplacing

- Event 70 - transporting empty transporter from emplacement drift to WHB.

The analysis assessed each of these scenarios as medium risk to personnel safety.

Mitigation of events 31,54 , and 70 will be provided by:

- Battery backup-power is not expected to be used so no batteries are present

- Using fire resistant cable insulation

- Minimizing the use and availability of combustible fuels in the development areas (Section 6.5) and maintaining the seal integrity and fire rating of the barrier between development and emplacement areas (Criterion 4.2.3.3).

The maximum damage potential of a fire in the emplacement fire area is undetermined. (See Section 7.5.8)

\subsection{IMPORTANT TO SAFETY EQUIPMENT}

Important-to-radiological-safety SSCs are those that have a safety or waste isolation significance as described by the quality level definitions in Section 2 .

Quality Level 1 and Quality Level 2 systems or SSCs that have been identified in this report as potential fire hazards are: 
- Operations, Monitoring, and Control System (QL-2)

- WP Transporter (QL-1)

- Locomotives (QL-1)

- Covered Shuttlecars (QL-2)

- Decontamination Equipment (QL-2)

- Modified Waste Package Transporter (QL-1)

- Multi-Purpose Hauler (QL-2).

Potential fire hazards for these systems are identified for these systems in Section 7.5. Mitigation of hazards to QL-1 and QL-2 systems will be provided by following the recommendations in Sections 7.5.1.2, 7.5.4.2, and 7.5.5.2. Implementation of the proposed hazards mitigation will provide a satisfactory level of fire protection that will meet applicable NRC regulations and DOE fire protection orders.

\subsection{CRITICAL PROCESS EQUIPMENT}

This criterion does not apply to the emplacement phase of the repository.

\subsection{EMERGENCY PLANNING}

The operating contractor will have the responsibility for developing and maintaining the emergency action plans for the emplacement operations. The plan will be NRC compliant.

Successful implementation of the emergency plan requires that a central operations control point be provided to handle fire emergencies. The control point would address underground operations, communications and fire status.

\subsection{FIRE DEPARTMENT/BRIGADE RESPONSE}

A fire brigade will be established (Criterion 4.2.5.1) for manual response for the MGR. The scope of their activities for subsurface response needs to be evaluated further. Offsite assistance will not be credited in this evaluation (Criterion 4.2.2.4).

\subsection{RECOVERY POTENTIAL}

The ability to recover from a credible subsurface fire is considered acceptable. Physical damage to the facility and its contents will be limited by the proposed fire protection systems and the use of fire-resistant or noncombustible material for construction and operation.

The adverse effects from fire protection systems should not be significant because water-based systems are not presently being selected.

Unacceptable levels of damage, caused by a credible fire, are not postulated due to the use of redundant fire-extinguishing systems for important-to-radiological-safety systems. 


\subsection{SECURITY AND SAFEGUARDS}

Access into the emplacement phase of the repository will be limited to personnel authorized by the use of protective force personnel and a personnel identification system. The security and safeguards, identified within the Safeguards and Security System Description Document [(CRWMS M\&O 1999z, p. 5) Assumption 5.3], will be addressed under future activities. 


\section{CONCLUSIONS}

This technical report identifies fire hazards and proposes their mitigation for the repository subsurface preliminary fire protection system. The proposed mitigation establishes the minimum level of fire protection to meet NRC regulations, DOE fire protection orders, that ensure fire containment, adequate life safety provisions, and minimize property loss. Equipment requiring automatic fire-extinguishing systems is identified.

This document may be affected by technical product input information that requires confirmation. Any changes to the document that may occur, as a result of completing the confirmation activities will be reflected in subsequent revisions. The status of the technical product input information quality can be confirmed by review of the DIRS database.

The subsurface fire hazards that are identified can be adequately mitigated.

The results from this report are preliminary and cannot be used as input into documents supporting procurement, fabrication, or construction.

\subsection{DEVELOPMENT FIRE AREA}

The preliminary assessment of this technical report, for the Development Fire Area, is that implementation of the proposed hazard mitigations and life safety provisions (Sections 6.5 and 6.6) will provide an acceptable level of fire protection that will meet applicable NRC regulations, DOE fire protection orders, and OSHA regulations.

\subsubsection{Required Hazard Mitigations}

The following hazard mitigations are required to meet the NRC regulations and DOE Orders in addition to the criteria of Section 4.2:

- Construct the ventilation barriers between fire area to comply with a minimum fire resistance rating of 2 hours (Section 6.2.3).

- Install automatic fire-extinguishing systems onboard the TBMs and maintenance railcars (Section 6.5.1.2).

- Install automatic fire-extinguishing systems onboard the diesel-powered mobile equipment (Section 6.5.1.2).

- Construct the maintenance railcar in accordance with NFPA 385 (Sections 6.5.1.2 and 6.8.1.1).

- Use fire-retardant hydraulic fluids (Section 6.5.1.2).

- Use fire-resistant cable insulation (Sections 6.5.1.2 and 6.5.2.2). 
- Select power backup batteries to minimize hydrogen offgassing (Sections 6.5.1.2 and 6.5.2.2).

- Install fire hose stations (Section 6.5.1.2).

- Use electrically-safe type nozzles on fire hoses (Section 6.8.3.9).

- Install electrical distribution equipment in cabinets (Section 6.5.2.2).

- Muck Conveyors (if used):

- Use fire-resistant conveyor belting (Section 6.5.3.2).

- Install automatic fire-extinguishing systems at conveyor drives and transfers (Section 6.5.3.2).

- Install slippage and alignment switches along conveyor (Section 6.5.3.2).

- Provide personal SRs and SCSRs (Section 6.6.4).

- Provide ERS or equivalent means of life-safety in emplacement drifts under construction (Section 6.6.3.4)

- Conduct TBM maintenance in the off-shifts (Section 6.6.3.4)

- Hot work will be done in accordance with NFPA 51B (Sections 6.8.1.3 and 6.8.2).

- Fire protection systems will be designed to withstand seismic activity (Section 6.10).

\subsubsection{Items Requiring Further Evaluation/Determination}

The following items are identified in the report as requiring further evaluation or establishment of design/test criteria:

- Determine high-value property dollar value loss estimates (Section 6.4).

- Select electrical cable fire-resistance criteria (Section 6.5.1.2)

- Determine conveyor belting fire-resistance test criteria (Section 6.5.3.2)

- Quantify size and duration of DBF (Section 6.5.6).

- Determine ventilation barrier fire resistance rating (Section 6.5.6). 
- Incorporate smoke and combustion byproduct flow and concentration into ventilation system design (Section 6.6.2).

- Evaluate use of ventilation intake shafts for emergency egress (Section 6.6.3.2).

- Evaluate need for external fire protection of cabling and motors for ventilation system to assist in smoke removal (Section 6.6.3.4).

- Evaluate egress routes, etc. and evacuation plan/procedure as proposed in the emergency action plan (Section 6.6.3.4).

- Determine design and location of ERSs (Section 6.6.5).

- Determine fire extinguisher spacing (Section 6.8.3.8).

- Determine hose station spacing (Section 6.8.3.9).

- Select seismic activity design criteria (Section 6.10).

- Evaluate any damage potential to the natural barrier resulting from a release from water-based fire protection system (Section 6.11.2).

- Define responsibility for firefighting and rescue during construction (Section 6.15).

\subsection{EMPLACEMENT FIRE AREA}

The preliminary assessment of this technical report, for the Emplacement Fire Area, is that implementation of the proposed hazard mitigations and life safety provisions (Sections 7.5 and 7.6) will provide an acceptable level of fire protection that will meet applicable NRC regulations, DOE fire protection orders, and OSHA regulations.

\subsubsection{Required Hazard Mitigations}

The following hazard mitigations are required to meet the NRC regulations and DOE Orders in addition to the criteria of Section 4.2:

- Install redundant automatic fire-extinguishing systems onboard the emplacement gantry and the inspection gantry (Section 7.5.1.2).

- Install redundant automatic fire-extinguishing systems onboard the WP transporters (Section 7.5.1.2).

- Install redundant automatic fire-extinguishing systems onboard the transport locomotives (Section 7.5.1.2). 
- Install redundant automatic fire-extinguishing systems onboard the diesel-powered waste-recovery/restoration equipment (Section 7.5.1.2).

- Install electrical distribution equipment in alcoves (Section 7.5.4.2).

- Install electrical distribution equipment in cabinets (Section 7.5.4.2).

- Use fire-resistant cable insulation (Section 7.5.4.2).

- Provide personal SRs and SCSRs (Section 7.6.4).

- Fire protection systems will be designed to withstand seismic activity (Section 7.10).

\subsubsection{Items Requiring Further Evaluation/Determination}

The following items are identified in the report as requiring further evaluation:

- Determine high-value property dollar value loss estimates (Section 7.4).

- Determine electrically powered specialty waste recovery equipment fire protection needs (Section 7.5.2.2).

- Select electrical cable fire-resistance criteria (Section 7.5.4.2).

- Determine OMCS fire protection needs (Section 7.5.5.2).

- Determine the DBF scenario and quantify size and duration (Section 7.5.8).

- Determine the MPFL for the worst-case DBF (Section 7.5.8.1).

- Evaluate the effects of fire-extinguishing system agents on nuclear safety (Sections 7.5.8.2 and 7.8.3).

- Determine the mitigation required for the worst-case DBF (Section 7.5.8.2).

- Incorporate smoke and combustion byproduct flow and concentration into ventilation system design (Section 7.6.2).

- Evaluate ERS design for the impact of emplacement thermal and nuclear effects (Section 7.6.5).

- Evaluate the need for manual fire-emergency response (Section 7.8.3).

- Select seismic activity design criteria (Section 7.10). 
- Define the scope of activity for the fire department/brigade response to repository subsurface emergencies (Section 7.15).

- Update the security and safeguards required for the repository subsurface facility (Section 7.17 


\section{INTENTIONALLY LEFT BLANK}




\section{REFERENCES}

This document may be affected by technical product input information that requires confirmation. Any changes to the document that may occur, as a result of completing the confirmation activities will be reflected in subsequent revisions. The status of the input information quality may be confirmed by review of the Document Input Reference System database.

\subsection{DOCUMENTS CITED}

BSC (Bechtel SAIC Company) 2001. Lower-Temperature Subsurface Layout and Ventilation Concepts. ANL-WER-MD-000002 REV 00. Las Vegas, Nevada: Bechtel SAIC Company. ACC: MOL.20010718.0225.

CRWMS M\&O (Civilian Radioactive Waste Management System Management and Operating Contractor) 1993. Non-Gassy Mine Classification Analysis. BABE00000-01717-0200-00115 REV 00. Las Vegas, Nevada: CRWMS M\&O. ACC: NNA.19940125.0004.

CRWMS M\&O 1994. Subsurface Fire Hazard Analysis. BABFAH000-01717-0200-00121 REV 00. Las Vegas, Nevada: CRWMS M\&O. ACC: MOL.19951103.0173.

CRWMS M\&O 1998a. Subsurface Fire Hazards Analysis. BABFAH000-01717-0200-00121 REV 01. Las Vegas, Nevada: CRWMS M\&O. ACC: MOL.19980414.0448.

CRWMS M\&O 1998b. Ventilation Needs During Construction. BCAJ00000-01717-0200-00001 REV 00. Las Vegas, Nevada: CRWMS M\&O. ACC: MOL.19980903.0875.

CRWMS M\&O 1998c. Mobile Waste Handling Support Equipment. BCAF00000-01717-0200-00006 REV 00. Las Vegas, Nevada: CRWMS M\&O. ACC: MOL.19980819.0397.

CRWMS M\&O 1998d. Emplacement Drift Invert Structural Design Analysis. BBDC00000-01717-020000001 REV 01. Las Vegas, Nevada: CRWMS M\&O. ACC: MOL.19980625.0366.

CRWMS M\&O 1999a. Classification of the MGR Canistered Spent Nuclear Fuel Disposal Container System. ANL-CDC-SE-000001 REV 00. Las Vegas, Nevada: CRWMS M\&O. ACC: MOL.19990928.0143.

CRWMS M\&O 1999b. Classification of the MGR Defense High-Level Waste Disposal Container System. ANL-DDC-SE-000001 REV 00. Las Vegas, Nevada: CRWMS M\&O. ACC: MOL.19990928.0142. 
CRWMS M\&O 1999c. Classification of the MGR DOE Spent Nuclear Fuel Disposal Container System. ANL-EDC-SE-000001 REV 00. Las Vegas, Nevada: CRWMS M\&O. ACC:

MOL.19990928.0141.

CRWMS M\&O 1999d. Classification of the MGR Ground Control System. ANL-GCS-SE-000001 REV 00. Las Vegas, Nevada: CRWMS M\&O. ACC: MOL.19990928.0217.

CRWMS M\&O 1999e. Classification of the MGR Muck Handling System. ANL-MHS-SE-000001 REV 00. Las Vegas, Nevada: CRWMS M\&O. ACC: MOL.19990928.0212.

CRWMS M\&O 1999f. Classification of the MGR Non-Fuel Components Disposal Container System. ANL-NDC-SE-000001 REV 00. Las Vegas, Nevada: CRWMS M\&O. ACC: MOL.19990928.0140.

CRWMS M\&O 1999g. Classification of the MGR Operations Monitoring and Control System. ANL-OMC-SE-000001 REV 00. Las Vegas, Nevada: CRWMS M\&O. ACC: MOL.19990927.0474.

CRWMS M\&O 1999h. Classification of the MGR Performance Confirmation Emplacement Drift Monitoring System. ANL-PCM-SE-000001 REV 00. Las Vegas, Nevada: CRWMS M\&O. ACC: MOL.19990928.0199.

CRWMS M\&O 1999i. Classification of the MGR Performance Confirmation Waste Isolation Verification/Validation System. ANL-PCV-SE-000001 REV 00. Las Vegas, Nevada: CRWMS M\&O. ACC: MOL.19990928.0193.

CRWMS M\&O 1999j. Classification of the MGR Subsurface Compressed Air System. ANL-SCA-SE-000001 REV 00. Las Vegas, Nevada: CRWMS M\&O. ACC: MOL.19990928.0198.

CRWMS M\&O 1999k. Classification of the MGR Subsurface Closure and Seal System. ANL-SCS-SE-000001 REV 00. Las Vegas, Nevada: CRWMS M\&O. ACC: MOL.19990928.0145.

CRWMS M\&O 19991. Classification of the MGR Subsurface Development Transportation System. ANL-SDT-SE-000001 REV 00. Las Vegas, Nevada: CRWMS M\&O. ACC: MOL.19990928.0197.

CRWMS M\&O 1999m. Classification of the MGR Subsurface Electrical Distribution System. ANL-SED-SE-000001 REV 00. Las Vegas, Nevada: CRWMS M\&O. ACC:

MOL.19990928.0195. 
CRWMS M\&O 1999n. Classification of the MGR Subsurface Excavation System. ANL-SES-SE-000001 REV 00. Las Vegas, Nevada: CRWMS M\&O. ACC: MOL.19990928.0194.

CRWMS M\&O 1999o. Classification of the MGR Subsurface Emplacement Transportation System. ANL-SET-SE-000001 REV 00. Las Vegas, Nevada: CRWMS M\&O. ACC: MOL.19990928.0126.

CRWMS M\&O 1999p. Classification of the MGR Subsurface Fire Protection System. ANL-SFR-SE-000001 REV 00. Las Vegas, Nevada: CRWMS M\&O. ACC: MOL.19990928.0192.

CRWMS M\&O 1999q. Classification of the MGR Subsurface Facility System. ANL-SFS-SE-000001 REV 00. Las Vegas, Nevada: CRWMS M\&O. ACC: MOL.19990928.0214.

CRWMS M\&O 1999r. Classification of the MGR Subsurface Ventilation System. ANL-SVS-SE-000001 REV 00. Las Vegas, Nevada: CRWMS M\&O. ACC: MOL.19990928.0219.

CRWMS M\&O 1999s. Classification of the MGR Subsurface Water Collection/Removal System. ANL-SWC-SE-000001 REV 00. Las Vegas, Nevada: CRWMS M\&O. ACC: MOL.19990928.0127.

CRWMS M\&O 1999t. Classification of the MGR Subsurface Water Distribution System. ANL-SWD-SE-000001 REV 00. Las Vegas, Nevada: CRWMS M\&O. ACC:

MOL.19990928.0220.

CRWMS M\&O 1999u. Classification of the MGR Uncanistered Spent Nuclear Fuel Disposal Container System. ANL-UDC-SE-000001 REV 00. Las Vegas, Nevada: CRWMS M\&O. ACC: MOL.19990928.0216.

CRWMS M\&O 1999v. Classification of the MGR Naval Spent Nuclear Fuel Disposal Container System: ANL-VDC-SE-000001 REV 00. Las Vegas, Nevada: CRWMS M\&O. ACC: MOL.19990928.0218.

CRWMS M\&O 1999w. Subsurface Fire Protection System Description Document. BCA000000-01717-1705-00006 REV 00. Two volumes. Las Vegas, Nevada: CRWMS M\&O. ACC: MOL.19990720.0206.

CRWMS M\&O 1999x. Subsurface Electrical Distribution System Description Document. BCA000000-01717-1705-00005 REV 00. Two volumes. Las Vegas, Nevada: CRWMS M\&O. ACC: MOL.19990609.0155. 
CRWMS M\&O 1999y. Subsurface Facilities Broad Based Risk Analysis Report. TDR-EBS-MG-000001 REV 00. Las Vegas, Nevada: CRWMS M\&O. ACC: MOL.20000111.0195.

CRWMS M\&O 1999z. Safeguards and Security System Description Document. BCB000000-01717-1705-00011 REV 00. Las Vegas, Nevada: CRWMS M\&O. ACC: MOL.19990720.0205.

CRWMS M\&O 2000a. Safety Basis Report. TDR-CRW-SE-000008 REV 00 ICN 01. Las Vegas, Nevada: CRWMS M\&O. ACC: MOL.20000908.0008.

CRWMS M\&O 2000b. Subsurface Facility System Description Document. SDD-SFS-SE-000001 REV 01. Las Vegas, Nevada: CRWMS M\&O. ACC: MOL.20000807.0078.

CRWMS M\&O 2000c. Subsurface Ventilation System Description Document. SDD-SVS-SE-000001 REV 01. Las Vegas, Nevada: CRWMS M\&O. ACC: MOL.20000803.0356.

CRWMS M\&O 2000d. Subsurface Repository Integrated Control System Design. ANL-MGR-CS-000001 REV 00. Las Vegas, Nevada: CRWMS M\&O. ACC: MOL.20000321.0284.

CRWMS M\&O 2000e. MGR External Events Hazards Analysis. ANL-MGR-SE-000004 REV 00. Las Vegas, Nevada: CRWMS M\&O. ACC: MOL.20000310.0069.

CRWMS M\&O 2000f. Bottom/Side Lift Gantry Conceptual Design. ANL-WES-ME-000003 REV 01. Las Vegas, Nevada: CRWMS M\&O. ACC: MOL.20000420.0399.

CRWMS M\&O 2000g. Waste Package Transport and Transfer Alternatives. ANL-WES-ME-000001 REV 00. Las Vegas, Nevada: CRWMS M\&O. ACC: MOL.20000317.0261.

CRWMS M\&O 2000h. Monitored Geologic Repository Internal Hazards Analysis. ANL-MGR-SE-000003 REV 00. Las Vegas, Nevada: CRWMS M\&O. ACC: MOL.20000310.0070.

CRWMS M\&O 2001a. Classification of the MGR Emplacement Drift System. ANL-EDS-SE-000001 REV 01. Las Vegas, Nevada: CRWMS M\&O. ACC: MOL.20010227.0043.

CRWMS M\&O 2001b. Classification of the MGR Waste Emplacement/Retrieval System. ANL-WES-SE-000001 REV 01. Las Vegas, Nevada: CRWMS M\&O. ACC: MOL.20010227.0016. 
CRWMS M\&O 2001c. Technical Work Plan for Subsurface Design Section FY 01 Work Activities. TWP-MGR-MG-000001 Rev 01, Addendum D. Las Vegas, Nevada: CRWMS M\&O. ACC: MOL.20010417.0455.

Curry, P.M. 2001. Monitored Geologic Repository Project Description Document. TDR-MGR-SE-000004 REV 02 ICN 02. Las Vegas, Nevada: Bechtel SAIC Company. ACC: MOL.20010628.0224.

DOE (U.S. Department of Energy) 2000a. Quality Assurance Requirements and Description. DOE/RW-0333P, Rev. 10. Washington, D.C.: U.S. Department of Energy, Office of Civilian Radioactive Waste Management. ACC: MOL.20000427.0422.

DOE 2000b. Emergency Management Plan. PLN-CRW-EM-000001, Rev. 0. Las Vegas, Nevada: U.S. Department of Energy, Office of Civilian Radioactive Waste Management. ACC: MOL.20000801.0003.

DOE 2001. OCRWM Lessons Learned Program Database Summary Sheets (2) and Copies of Six "Lessons Learned" Listed Under "Fire" and "Fire Pump." [Washington, D.C.]: U.S. Department of Energy, Office of Civilian Radioactive Waste Management. ACC: MOL.20010409.0369.

\subsection{REGULATIONS, STANDARDS AND DIRECTIVES CITED}

10 CFR (Code of Federal Regulation) 71. Energy: Packaging and Transportation of Radioactive Material. Readily available.

29 CFR 1910. Labor: Occupational Safety and Health Standards. Readily available.

29 CFR 1926. Labor: Safety and Health Regulations for Construction. Readily available.

30 CFR 57. Mineral Resources: Safety and Health Standards. Underground Metal and Nonmetal Mines. Readily available.

DOE Order 420.1, Change 3. 2000. Facility Safety. Washington, D.C.: U.S. Department of Energy. Readily available.

DOE G 440.1-5. 1995. Implementation Guide for Use with DOE Orders 420.1 and 440.1 Fire Safety Program. Washington, D.C.: U.S. Department of Energy. Readily available.

NFPA (National Fire Protection Association) 10. 1998. Standard for Portable Fire Extinguishers. 1998 Edition. Quincy, Massachusetts: National Fire Protection Association. TIC: 241333.

NFPA 13. 1999. Standard for the Installation of Sprinkler Systems. 1999 Edition. Quincy, Massachusetts: National Fire Protection Association. TIC: 247109. 
NFPA 14. 2000. Standard for the Installation of Standpipe and Hose Systems. 2000 Edition. Quincy, Massachusetts: National Fire Protection Association. TIC: 249673.

NFPA 17. 1998. Standard for Dry Chemical Extinguishing Systems. 1998 Edition. Quincy, Massachusetts: National Fire Protection Association. TIC: 245935.

NFPA 24. 1995. Standard for the Installation of Private Fire Service Mains and Their Appurtenances. 1995 Edition. Quincy, Massachusetts: National Fire Protection Association. TIC: 241328.

NFPA 30. 2000. Flammable and Combustible Liquids Code. 2000 Edition. Quincy, Massachusetts: National Fire Protection Association. TIC: 249674.

NFPA 51B. 1999. Standard for Fire Prevention During Welding, Cutting, and Other Hot Work. 1999 Edition. Quincy, Massachusetts: National Fire Protection Association. TIC: 245936.

NFPA 70. 1998. National Electrical Code. 1999 Edition. Quincy, Massachusetts: National Fire Protection Association. TIC: 240528.

NFPA 72. 1999. National Fire Alarm Code. 1999 Edition. Quincy, Massachusetts: National Fire Protection Association. TIC: 247112.

NFPA 101. 2000. Life Safety Code. 2000 Edition. Quincy, Massachusetts: National Fire Protection Association. TIC: 247536.

NFPA 122. 2000. Standard for Fire Prevention and Control in Underground Metal and Non-Metal Mines. 2000 Edition. Quincy, Massachusetts: National Fire Protection Association. TIC: 249675.

NFPA 130. 2000. Standard for Fixed Guideway Transit and Passenger Rail Systems. 2000 Edition. Quincy, Massachusetts: National Fire Protection Association. TIC: 249662.

NFPA 241. 2000. Standard for Safeguarding Construction, Alteration, and Demolition Operations. 2000 Edition. Quincy, Massachusetts: National Fire Protection Association. TIC: 249661.

NFPA 385. 2000. Standard for Tank Vehicles for Flammable and Combustible Liquids. 2000 Edition. Quincy, Massachusetts: National Fire Protection Association. TIC: 249663.

NFPA 502. 1998. Standard for Road Tunnels, Bridges, and Other Limited Access Highways. 1998 Edition. Quincy, Massachusetts: National Fire Protection Association. TIC: 249664.

NFPA 520. 1999. Standard on Subterranean Spaces. 1999 Edition. Quincy, Massachusetts: National Fire Protection Association. TIC: 249660. 
NFPA 780. 1997. Standard for the Installation of Lightning Protection Systems. 1997 Edition. Quincy, Massachusetts: National Fire Protection Association. TIC: 240298.

NFPA 801. 1998. Standard for Fire Protection for Facilities Handling Radioactive Materials. 1998 Edition. Quincy, Massachusetts: National Fire Protection Association. TIC: 241330.

NFPA 2001. 2000. Standard on Clean Agent Fire Extinguishing Systems. 2000 Edition. Quincy, Massachusetts: National Fire Protection Association. TIC: 249694.

NRC (U.S. Nuclear Regulatory Commission) 1981. "Fire Protection Program." Section 9.5.1 of Standard Review Plan for the Review of Safety Analysis Reports for Nuclear Power Plants.

LWR Edition. NUREG-0800, Rev 3. Washington, D.C.: U.S. Nuclear Regulatory Commission. TIC: 248392.

Regulatory Guide 1.189. 2001. Fire Protection for Operating Nuclear Power Plants. Washington, D.C.: U.S. Nuclear Regulatory Commission. Readily Available.

\subsection{PROCEDURES CITED}

AP-2.21Q, Rev. 1, ICN 0, BSCN 001. Quality Determinations and Planning for Scientific, Engineering, and Regulatory Compliance Activities. Washington, D.C.: U.S. Department of Energy, Office of Civilian Radioactive Waste Management. ACC: MOL.20010212.0018.

AP-3.11Q, Rev. 2, ICN 0. Technical Reports. Washington, D.C.: U.S. Department of Energy, Office of Civilian Radioactive Waste Management. ACC: MOL.20010405.0010.

AP-3.15Q, Rev. 2, ICN 1. Managing Technical Product Inputs. Washington, D.C.: U.S. Department of Energy, Office of Civilian Radioactive Waste Management. ACC: MOL.20010405.0011.

AP-ESH-004, Rev. 0, ICN 1, BSCN 001, ECN 001. Occupational Safety and Health Program. Washington, D.C.: U.S. Department of Energy, Office of Civilian Radioactive Waste Management. ACC: MOL.20010709.0406.

AP-ESH-008, Rev. 0, ICN 0, BSCN 001, ECN 001. Hazards Analysis System. Washington, D.C.: U.S. Department of Energy, Office of Civilian Radioactive Waste Management. ACC: MOL.20010430.0069.

AP-ESH-009, Rev. 1, ICN 0, BSCN 001. Application of the Grading Approach to Activities Subject to the Integrated Safety Management Quality Assurance Program (ISMQAP). Washington, D.C.: U.S. Department of Energy, Office of Civilian Radioactive Waste Management. ACC: MOL.20010212.0230.

LP-ESH-010-M\&O, Rev. 0, ICN 1, BSCN 001, ECN 003. Emergency Management. Washington, D.C.: U.S. Department of Energy, Office of Civilian Radioactive Waste Management. ACC: MOL.20010702.0151. 


\subsection{CORRESPONDENCE CITED}

Dyer, J.R. 1999. "Interim Guidance Pending Issuance of New U.S. Nuclear Regulatory Commission (NRC) Regulations for Yucca Mountain, Nevada." Letter from J.R. Dyer (DOE/YMSCO) to D.R. Wilkins (CRWMS M\&O), June 18, 1999, OL\&RC:AVG:1435, with enclosure. ACC: MOL.19990623.0026; MOL.19990623.0027. 


\section{ATTACHMENTS}

\section{ATTACHMENT I}

Construction Equipment Hazards Inventory

Pages I-1 to I-12

ATTACHMENT II

Emplacement Equipment Hazards Inventory

.Pages II-1 to II-6 
INTENTIONALLY LEFT BLANK 


\section{CONSTRUCTION EQUIPMENT HAZARDS INVENTORY}




\section{INTENTIONALLY LEFT BLANK}




\section{FIRE HAZARD DESCRIPTION OF CONSTRUCTION EQUIPMENT}

Equipment Identifier

Equipment Utilization

Size (Diameter)

Combustible Fluids

Hydraulic Oil

Main Reservoir

Rock Drills

Clamshell

Conveyor tailpiece

Cylinder Accumulators

Supply/Return Lines

Pumps

Lubricating Oil

Grease
TBM

Main Drift Excavation

7.62 meters (25 feet)

Quantity

liters (gallons)

note 1

note 1

note 1

note 1

note 1

note 1

note 1

note 1

note 1

\section{Electrical Transformer Yes Number note 1 Capacity note 1

Electrical Cable Yes Type note 1 Length note 1 \\ SCSRs \\ Yes Number note 1}

Portable Fire Extinguishers Yes Number note 1 Type $A B C$

Fire Hazard Mitigation Yes Type Pre-engineered automatic extinguishing system Extinguishing Agent Type Multipurpose dry chemical

Note 1: This information is not available at this time and will be added at a later date. 


\section{FIRE HAZARD DESCRIPTION OF CONSTRUCTION EQUIPMENT}

Equipment Identifier

Equipment Utilization

Size (Diameter)

Combustible Fluids

Hydraulic Oil

Main Reservoir

Rock Drills

Clamshell

Conveyor tailpiece

Cylinder Accumulators

Supply/Return Lines

Pumps

Lubricating Oil

Grease
TBM

Emplacement Drift Excavation

5.5 meters (18 feet)

Quantity
liters (gallons)
note 1
note 1
note 1
note 1
note 1
note 1
note 1
note 1
note 1

$\begin{array}{llllll}\text { Electrical Transformer } & \text { Yes } & \text { Number } & \text { note } 1 \text { Capacity } & \text { note 1 } \\ \text { Electrical Cable } & \text { Yes } & \text { Type } & \text { note } 1 & \text { Length } & \text { note 1 } \\ \text { SCSRs } & \text { Yes } & \text { Number } & \text { note } 1 & & \end{array}$

Portable Fire Extinguishers Yes Number note 1 Type $A B C$

Fire Hazard Mitigation Yes Type Pre-engineered automatic extinguishing system

Extinguishing Agent Type Multipurpose dry chemical

Note 1: This information is not available at this time and will be added at a later date. 


\section{FIRE HAZARD DESCRIPTION OF CONSTRUCTION EQUIPMENT}

Equipment Identifier

Equipment Utilization

Size

Combustible Fluids

Hydraulic Oil

Lubricating Oil

Grease

Used Oil
Maintenance Railcar

Equipment Maintenance

note 1

Quantity

liters (gallons)

note 1

note 1

note 1

note 1
Electrical Transformer Electrical Cable
No Number note 1 Type
N/A Capacity note 1 Length

\section{N/A}

note 1

Portable Fire Extinguishers Yes Number note 1 Type $A B C$

Fire Hazard Mitigation Yes Type Pre-engineered automatic extinguishing system Extinguishing Agent Type Multipurpose dry chemical

Note 1: This information is not available at this time and will be added at a later date. 


\section{FIRE HAZARD DESCRIPTION OF CONSTRUCTION EQUIPMENT}

Equipment Identifier

Equipment Utilization

Size

Combustible Fluids

Hydraulic Oil

Lubricating Oil

Grease

Used Oil
Explosives Railcar

Drill and blast material transport

note 1

Quantity

liters (gallons)

note 1

note 1

note 1

note 1

Electrical Transformer No Number N/A Capacity N/A Electrical Cable note 1 Type note 1 Length note 1

Portable Fire Extinguishers Yes Number note 1 Type $A \bar{B} C$ Fire Hazard Mitigation note 1 Type note 1 Extinguishing Agent Type note 1

Note 1: This information is not available at this time and will be added at a later date. 


\section{FIRE HAZARD DESCRIPTION OF CONSTRUCTION EQUIPMENT}

Equipment Identifier

Equipment Utilization

Size (Cutting Profile)

Combustible Fluids

Hydraulic Oil

Main Reservoir

Cylinder Accumulators

Supply/Return Lines

Pumps

Lubricating Oil

Grease
Road Header Machine

Emplacement Drift Excavation

6.3m H X 9.0m W (20.6' X 29.4')

\section{Quantity}

liters (gallons)

note 1

note 1

note 1

note 1

note 1

note 1

$\begin{array}{llllll}\text { Electrical Transformer } & \text { note } 1 & \text { Number } & \text { note } 1 & \text { Capacity } & \text { note } 1 \\ \text { Electrical Cable } & \text { Yes } & \text { Type } & \text { note } 1 & \text { Length } & \text { note } 1\end{array}$

Portable Fire Extinguishers Yes Number note 1 Type ABC

Fire Hazard Mitigation Yes Type Pre-engineered automatic extinguishing system

Extinguishing Agent Type Multipurpose dry chemical

Note 1: This information is not available at this time and will be added at a later date. 


\section{FIRE HAZARD DESCRIPTION OF CONSTRUCTION EQUIPMENT}

Equipment Identifier

Equipment Utilization

Size

Combustible Fluids

Hydraulic Oil

Main Reservoir

Cylinder Accumulators

Supply/Return Lines

Pumps

Lubricating Oil

Grease
Drill Jumbo

Excavation and Roof Bolting

note 1

Quantity

liters (gallons)

note 1

note 1

note 1

note 1

note 1

note 1
Electrical Transformer Electrical Cable note 1 Number

Yes Type note 1 Capacity note 1 Length note 1

note 1

Portable Fire Extinguishers Yes Number note 1 Type ABC

Fire Hazard Mitigation Yes Type Pre-engineered automatic extinguishing system

Extinguishing Agent Type Multipurpose dry chemical

Note 1: This information is not available at this time and will be added at a later date. 


\section{FIRE HAZARD DESCRIPTION OF CONSTRUCTION EQUIPMENT}

Equipment Identifier

Equipment Utilization

Size

Combustible Fluids

Hydraulic Oil

Main Reservoir

Cylinder Accumulators

Supply/Return Lines

Pumps

Lubricating Oil

Grease
Load Haul Dump Loader

General Clean-up

note 1

Quantity

liters (gallons)

note 1

note 1

note 1

note 1

note 1

note 1

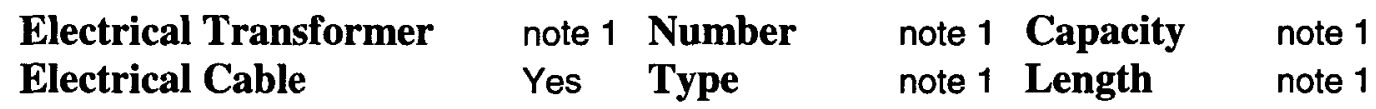

Portable Fire Extinguishers Yes Number note 1 Type ABC

$\begin{array}{lll}\text { Fire Hazard Mitigation } & \text { Yes Type Pre-engineered automatic extinguishing system } \\ \text { Extinguishing Agent Type } & \text { Multipurpose dry chemical }\end{array}$

Other Combustibles Rubber Tires

Note 1: This information is not available at this time and will be added at a later date. 
FIRE HAZARD DESCRIPTION OF CONSTRUCTION EQUIPMENT

Equipment Identifier

Equipment Utilization

Size

Combustible Fluids

Hydraulic Oil

Main Reservoir

Cylinder Accumulators

Supply/Return Lines

Pumps

Lubricating Oil

Grease
Electric Crane Car

General Maintenance

note 1

Quantity

liters (gallons)

note 1

note 1

note 1

note 1

note 1

note 1

\section{Electrical Transformer \\ note 1 Number \\ Yes Type \\ Portable Fire Extinguishers Yes Number note 1 Type $A B C$ note 1 Type $\begin{array}{ll}\text { Fire Hazard Mitigation note } 1 \\ \text { Extinguishing Agent Type } & \text { note } 1\end{array}$ \\ note 1 Capacity note 1 \\ note 1 Length note 1}

Note 1: This information is not available at this time and will be added at a later date. 


\section{FIRE HAZARD DESCRIPTION OF CONSTRUCTION EQUIPMENT}

Equipment Identifier

Equipment Utilization

Size (Boom Length)

Combustible Fluids

Hydraulic Oil

Main Reservoir

Cylinder Accumulators

Supply/Return Lines

Pumps

Lubricating Oil

Grease
Electric Manlift

General Maintenance

note 1

Quantity

liters (gallons)

note 1

note 1

note 1

note 1

note 1

note 1

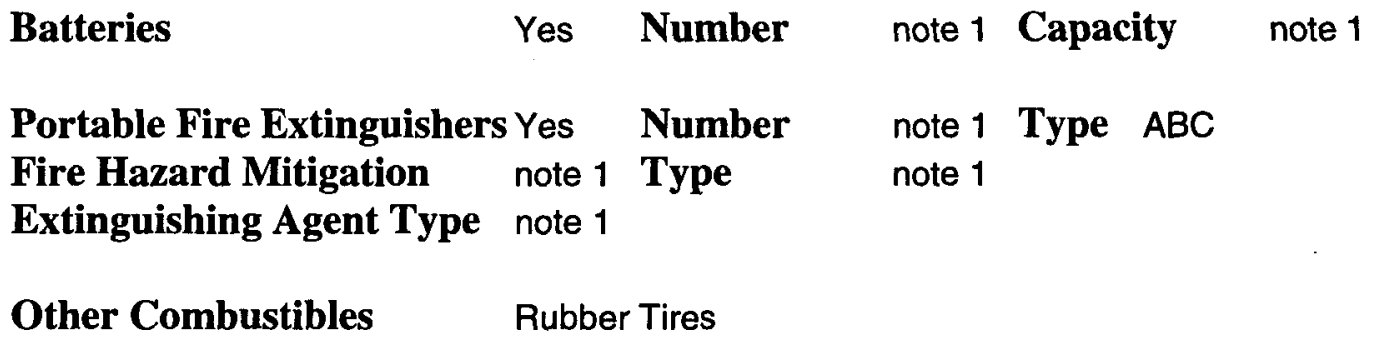

Note 1: This information is not available at this time and will be added at a later date. 


\section{FIRE HAZARD DESCRIPTION OF CONSTRUCTION EQUIPMENT}

Equipment Identifier

Equipment Utilization

Size

Combustible Fluids

Hydraulic Oil

Lubricating Oil

Grease
Electric Locomotive

Transportation

note 1

Quantity

liters (gallons)

note 1

note 1

note 1
Electrical Transformer Electrical Cable note 1 Number

note 1 Type note 1 Capacity

note 1 Length note 1

note 1

Portable Fire Extinguishers Yes Number note 1 Type $A B C$

Fire Hazard Mitigation note 1 Type note 1

Extinguishing Agent Type note 1

Other Hazards Storage Batteries Type note 1

Note 1: This information is not available at this time and will be added at a later date. 


\section{FIRE HAZARD DESCRIPTION OF CONSTRUCTION EQUIPMENT}

Equipment Identifier

Equipment Utilization

Size

Combustible Fluids

Diesel Fuel

Hydraulic Oil

Lubricating Oil

Grease
Diesel Locomotive

Transportation

note 1

Quantity

liters (gallons)

note 1

note 1

note 1

note 1

\section{Electrical Cable}

note 1 Type

note 1 Length

note 1

Portable Fire Extinguishers Yes Number note 1 Type ABC

Fire Hazard Mitigation Yes Type Pre-engineered automatic extinguishing system Extinguishing Agent Type Multipurpose dry chemical

Other Hazards Storage Batteries Type note 1

Note 1: This information is not available at this time and will be added at a later date. 
INTENTIONALLY LEFT BLANK 


\section{ATTACHMENT II}

\section{EMPLACEMENT EQUIPMENT HAZARDS INVENTORY}


INTENTIONALLY LEFT BLANK 


\section{FIRE HAZARD DESCRIPTION OF EMPLACEMENT EQUIPMENT}

Equipment Identifier

Equipment Utilization

Size

Combustible Fluids

Hydraulic Oil

Lubricating Oil

Grease
Emplacement Gantry

WP Emplacement

note 1

\author{
Quantity \\ liters (gallons) \\ note 1 \\ note 1 \\ note 1
}

$\begin{array}{llllll}\text { Electrical Transformer } & \text { note } 1 & \text { Number } & \text { note } 1 & \text { Capacity } & \text { note } 1 \\ \text { Electrical Cabinets } & \text { note } 1 & \text { Number } & \text { note } 1 & \text { Enclosure Type } & \text { note } 1 \\ \text { Electrical Cable } & \text { note } 1 & \text { Type } & \text { note } 1 & \text { Length } & \text { note } 1\end{array}$

Portable Fire Extinguishers No Number N/A Type N/A

Fire Hazard Mitigation Yes Type Automatic

Redundant Systems Yes

Extinguishing Agent Type note 1

Other Hazards note 1 Type note 1

Note 1: This information is not available at this time and will be added at a later date. 


\section{FIRE HAZARD DESCRIPTION OF EMPLACEMENT EQUIPMENT}

Equipment Identifier

Equipment Utilization

Size

Combustible Fluids

Hydraulic Oil

Lubricating Oil

Grease
Inspection Gantry

Emplacement Drift Monitoring

note 1

Quantity

liters (gallons)

note 1

note 1

note 1
Electrical Transformer Electrical Cabinets Electrical Cable

$$
\begin{array}{ll}
\text { note } 1 & \text { Number } \\
\text { note } 1 & \text { Number } \\
\text { note } 1 & \text { Type }
\end{array}
$$

note 1 Capacity note 1 Enclosure Type note 1 Length note 1

note 1

note 1
Portable Fire Extinguishers No Fire Hazard Mitigation Yes Redundant Systems Extinguishing Agent Type

Other Hazards
Number Type Yes

note 1
N/A Type N/A

Automatic

Note 1: This information is not available at this time and will be added at a later date. 


\section{FIRE HAZARD DESCRIPTION OF EMPLACEMENT EQUIPMENT}

Equipment Identifier

Equipment Utilization

Size

Combustible Fluids

Hydraulic Oil

Lubricating Oil

Grease
Gantry Carrier

Gantry Transport

note 1

Quantity

liters (gallons)

note 1

note 1

note 1
Electrical Transformer Electrical Cabinets Electrical Cable

$$
\begin{array}{ll}
\text { note } 1 & \text { Number } \\
\text { note } 1 & \text { Number } \\
\text { note } 1 & \text { Type }
\end{array}
$$

note 1 Capacity

note 1 Enclosure Type

note 1 Length note 1

note 1

note 1

Portable Fire Extinguishers No Number N/A Type N/A

Fire Hazard Mitigation No

Redundant Systems

No Type

N/A

Extinguishing Agent Type

N/A

note 1

Other Hazards

note 1 Type

note 1

Note 1: This information is not available at this time and will be added at a later date. 
FIRE HAZARD DESCRIPTION OF EMPLACEMENT EQUIPMENT

\author{
Equipment Identifier \\ Equipment Utilization \\ Size
}

Combustible Fluids

Hydraulic Oil

Lubricating Oil

Grease
Transport Locomotive

WP Transportation

note 1

\author{
Quantity \\ liters (gallons) \\ note 1 \\ note 1 \\ note 1
}

\begin{tabular}{|c|c|c|c|}
\hline $\begin{array}{l}\text { Electrical Transformer } \\
\text { Electrical Cabinets } \\
\text { Electrical Cable }\end{array}$ & $\begin{array}{l}\text { note } 1 \\
\text { note } 1 \\
\text { note } 1\end{array}$ & $\begin{array}{l}\text { Number } \\
\text { Number } \\
\text { Type }\end{array}$ & $\begin{array}{ll}\text { note } 1 & \text { Capacity } \\
\text { note } 1 & \text { Enclosure Type } \\
\text { note } 1 & \text { Length }\end{array}$ \\
\hline $\begin{array}{l}\text { Portable Fire Extinguisher } \\
\text { Fire Hazard Mitigation } \\
\text { Redundant Systems } \\
\text { Extinguishing Agent Type }\end{array}$ & $\begin{array}{l}\text { note } 1 \\
\text { Yes } \\
\text { Yes } \\
\text { note } 1\end{array}$ & $\begin{array}{l}\text { Number } \\
\text { Type }\end{array}$ & $\begin{array}{l}\text { note } 1 \text { Type note } 1 \\
\text { Automatic }\end{array}$ \\
\hline Other Hazards & note 1 & Type & note 1 \\
\hline
\end{tabular}

Note 1: This information is not available at this time and will be added at a later date. 


\section{FIRE HAZARD DESCRIPTION OF EMPLACEMENT EQUIPMENT}

Equipment Identifier

Equipment Utilization

Size

Combustible Fluids

Hydraulic Oil

Lubricating Oil

Grease
WP Transporter (with Transfer Deck)

WP Transportation

note 1

Quantity

liters (gallons)

note 1

note 1

note 1

$\begin{array}{llllll}\text { Electrical Transformer } & \text { note } 1 & \text { Number } & \text { note 1 } & \text { Capacity } & \text { note } 1 \\ \text { Electrical Cabinets } & \text { note } 1 & \text { Number } & \text { note } 1 & \text { Enclosure Type } & \text { note 1 } \\ \text { Electrical Cable } & \text { note } 1 & \text { Type } & \text { note } 1 & \text { Length } & \text { note } 1\end{array}$

Portable Fire Extinguishers note 1 Number note 1 Type note 1

Fire Hazard Mitigation Yes Type Automatic

Redundant Systems Yes

Extinguishing Agent Type note 1

Other Hazards note 1 Type note 1

Note 1: This information is not available at this time and will be added at a later date. 
Equipment Identifier

Equipment Utilization

Size

Combustible Fluids

Diesel Fuel

Hydraulic Oil

Lubricating Oil

Grease
Diesel-powered equipment

Abnormal waste recovery operations

note 1

Quantity

liters (gallons)

note 1

note 1

note 1

note 1

$\begin{array}{llllll}\text { Electrical Transformer } & \text { note } 1 & \text { Number } & \text { note } 1 & \text { Capacity } & \text { note } 1 \\ \text { Electrical Cabinets } & \text { note } 1 & \text { Number } & \text { note } 1 & \text { Enclosure Type } & \text { note } 1 \\ \text { Electrical Cable } & \text { note } 1 & \text { Type } & \text { note } 1 & \text { Length } & \text { note } 1\end{array}$

Portable Fire Extinguishers note 1 Number note 1 Type note 1

Fire Hazard Mitigation Yes Type Automatic

Redundant Systems Yes

Extinguishing Agent Type note 1

Other Hazards note 1 Type note 1

Note 1: This information is not available at this time and will be added at a later date. 